\title{
DAS CONSEQUÊNCIAS DA DEMONIZAÇÃO DA PLURALIDADE NAS ESCOLAS À LUZ DO ESTATUTO DA DIVERSIDADE SEXUAL E DE GÊNERO
}

\author{
THE CONSEQUENCES OF THE DEMONIZATION OF PLURALITY IN SCHOOLS \\ UNDER THE STATUTE OF SEXUAL \\ AND GENDER DIVERSITY
}

\section{LAS CONSECUENCIAS DE LA DEMONIZACIÓN DE LA PLURALIDAD EM LAS ESCUELAS A LA LUZ DEL ESTATUTO DE LA DIVERSIDAD SEXUAL Y DE GÉNERO}

\author{
VALERIA SiLVA GaLdino CARDIN \\ https://orcid.org/0000-0001-9183-0672 / http://lattes.cnpq.br/8121501433418182 / valeria@galdino.adv.br \\ Centro Universitário de Maringá - UNICESUMAR; Instituto Cesumar de Ciência, Tecnologia e Inovação - ICETI; \\ Universidade Estadual de Maringá - UEM \\ Maringá, PR, Brasil
}

RAISSA ARANTES TOBBIN https://orcid.org/0000-0002-3655-8407 / http://lattes.cnpq.br/ 5997745021125050 / tobbinraissa@hotmail.com Pontifícia Universidade Católica de Minas Gerais - PUC-MINAS Maringá, PR, Brasil

\begin{abstract}
RESUMO
É notório o crescimento, no cenário social brasileiro, do ataque à educação sexual e de gênero nas escolas. Os combatentes da denominada “Ideologia de Gênero" sustentam que o ensino voltado para a aceitação e para a discussão da pluralidade é um erro, que confunde e prejudica o desenvolvimento de crianças e adolescentes. Tal pauta, de natureza conservadora e discriminatória, e utilizada como força de manobra política, deflagra princípios norteadores do Estado Democrático de Direito e da Constituição Federal de 1988. Assim, esse trabalho tem por objetivo analisar as consequências da demonização dos estudos acerca de pluralidade à luz dos parâmetros educacionais estabelecidos pelo Estatuto da Diversidade Sexual e de Gênero, Projeto de Lei n 134/2018. Para tanto, utiliza-se o método teórico, fundamentado em pesquisa quantitativa e em revisão bibliográfica de obras, artigos científicos, legislação, jurisprudência e doutrina aplicáveis à temática e pertinentes à propositura de soluções à problemática.
\end{abstract}

Palavras-chave: Direito à Educação. Discurso do Ódio. Diversidade Sexual.

\section{ABSTRACT}

It is notorious the growth, in brazilian social scenario, of attacks towards sex and gender education in schools. The fighters of the called "Gender Ideology" hold that the teaching aimed at accepting and discussing plurality is a mistake, that confuses and impairs the development of children and adolescents. This agenda, highly conservative and discriminatory, used as a political move, offends the guiding principles of Democratic State of Law and Federal Constitution of 1988. Therefore, this work aims to analyze the consequences of the demonization of studies about plurality in the light of the educational parameters established in the Statute of Sexual and Gender Diversity, Law Project $n^{\circ} 134 / 2018$. For this, the theoretical method is used, based on quantitative research and bibliographical revision of books, scientific articles, legislation, jurisprudence and doctrine applicable to the thematic and pertinent to the proposal of solutions to the problematic.

Keywords: Right to Education. Hate Speech. Sexual Diversity. 


\section{RESUMEN}

Es notorio el crecimiento, en el escenario social brasileño, del ataque a la educación sexual y de género en las escuelas. Los combatientes de la denominada "Ideología de Género" sostienen que la enseñanza orientada hacia la aceptación y la discusión de la pluralidad es un error, que confunde y perjudica el desarrollo de niños y adolescentes. En este sentido, el trabajo tiene por objetivo analizar las consecuencias de la demonización de los estudios acerca de la pluralidad a la luz de los parámetros educativos establecidos por el Estatuto de la Diversidad Sexual y de Género, Proyeto de Ley $n^{\circ}$ 134/2018. Para ello, se utiliza el método teórico, fundamentado en investigación y en revisión bibliográfica de obras, artículos científicos, legislación, jurisprudencia y doctrina aplicables a la temática y pertinentes a la proposición de soluciones a la problemática.

Palabras clave: Derecho a la Educación. Discurso del Odio. Diversidad Sexual.

\section{SUMÁRIO}

INTRODUÇÃO; 1 GÊNERO E SEXUALIDADE; 2 A EDUCAÇÃO DE GÊNERO NAS ESCOLAS; 3 A IDEOLOGIA DE GÊNERO E O DISCURSO POLÍTICO; 4 AS CONSEQUÊNCIAS DA DEMONIZAÇÃO DA EDUCAÇÃO DE GÊNERO; 5 O DIREITO À EDUCAÇÃO À LUZ DO ESTATUTO DA DIVERSIDADE SEXUAL E DE GÊNERO; CONCLUSÃO; REFERÊNCIAS.

\section{INTRODUÇÃO}

O cenário social brasileiro vive um momento de grande tensão política que, por vezes, impede o diálogo, o crescimento e o aprimoramento de pautas essenciais para 0 desenvolvimento do país, tais como a economia, a educação, a saúde, o meio ambiente e o avanço tecnológico e científico. A principal consequência disso é a polarização de ideias e o fortalecimento de posicionamentos extremistas, que pouco contribuem para um ambiente moderado, crucial para a existência de um Estado Democrático de Direito. Nesse contexto, os que mais sofrem são os indivíduos pertencentes aos grupos considerados socialmente vulneráveis, a exemplo das minorias sexuais e de suas principais pautas políticas e sociais, que tendem a ser deixadas na obscuridade ou veementemente atacadas. É o que se vislumbra diante da onda de conservadorismo que parece reacender a imposição de valores morais e religiosos e que obsta a defesa da educação de gênero nas escolas, visto que a compreende como um erro e defende que a educação sexual deve ser restrita ao seio familiar.

Assim, os militantes que intentam a derrubada da "ideologia de gênero", termo cercado de imprecisões e dúvidas acerca do seu real sentido e abrangência, evidenciam o debate e as controvérsias que ainda existem em relação ao ensino e à aceitação da pluralidade sexual e de gênero no âmbito escolar que, diante de tal visão, poderia ter o condão de conturbar o “correto" desenvolvimento do indivíduo. Logo, o presente trabalho tem por objetivo analisar o termo "ideologia de gênero", utilizado, inúmeras vezes, como pauta de manobra política, e as 
ISSN 1981-3694

(DOI): $10.5902 / 1981369438872$

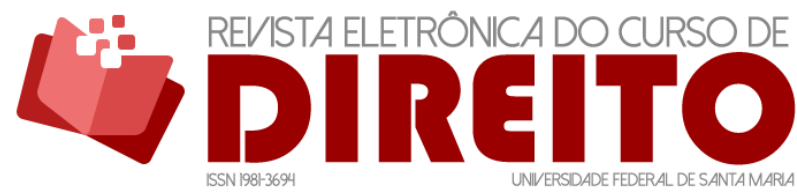

consequências da demonização na educação de gênero nas escolas brasileiras, uma vez que é fundamental, no presente contexto, a investigação acerca do papel da escola frente à aceitação da diversidade, da forma como esta deve ensinar e de quais seriam os eventuais limites da sua atuação ou, como recentemente alegam, “doutrinação”.

A presente pesquisa justifica-se diante dos alarmantes índices de discriminação e de preconceito que sofrem os indivíduos que representam ou se identificam com a causa LGBTQI+ no Brasil, que têm ocupado o topo em rankings mundiais que retratam a violência perpetrada contra tais cidadãos, que ainda possuem escassa legislação específica que proteja os seus direitos fundamentais e de personalidade. Para isso, utiliza-se o método teórico, fundamentado em pesquisa e revisão bibliográfica de obras, artigos científicos, notícias, legislação, documentos norteadores da Educação brasileira, jurisprudência e doutrina aplicáveis à temática e pertinentes à proposição de soluções à problemática. Inicialmente, o trabalho aborda os aspectos essenciais que envolvem a sexualidade e a identidade de gênero e a forma como tem sido estabelecida e norteada a educação de gênero nas escolas públicas brasileiras.

Posteriormente, apresenta-se a conceituação do termo "ideologia de gênero" e as principais polêmicas e indagações que este enseja no contexto social e político brasileiro, sendo apontadas, ainda, as possíveis consequências da demonização da educação de gênero à luz deste cenário. Por fim, o trabalho discute a proposta contida Projeto de Lei $n^{\circ} 134 / 2018$, conhecido como Estatuto da Diversidade Sexual e de Gênero, documento que, apesar de não possuir força legislativa, pode orientar ou, no mínimo, propor reflexões quanto à educação de gênero nas escolas.

\section{GÊNERO E SEXUALIDADE}

Sob a ótica cis-hetero-normativa, os gêneros são o feminino e o masculino, de forma que há um padrão de comportamento, de vestimentas, de cores, de educação, de sociabilidade, de conduta e de oportunidades profissionais e sociais para os meninos, e outro para as meninas. Assim, homens e mulheres possuem papéis distintos dentro do corpo e da lógica social: eles devem ser pais de família, provedores, trabalhadores, competitivos, fortes, não devem demonstrar suas fraquezas e emoções; enquanto que elas nascem para o casamento, para o cuidar da casa, do marido e dos filhos, para os afazeres domésticos e para o ócio. Nessa perspectiva, a sexualidade é tema da vida privada, da intimidade e não deve ser exposta ou discutida socialmente. A concepção do que é e da função do sexo são fatores altamente 
ISSN 1981-3694

(DOI): $10.5902 / 1981369438872$

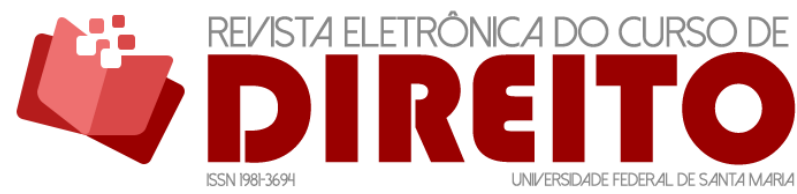

DAS CONSEQUÊNCIAS DA DEMONIZAÇÃO DA PLURALIDADE NAS ESCOLAS À LUZ DO ESTATUTO DA DIVERSIDADE SEXUAL E DE

GÊNERO

VALERIA SILVA GALDINO CARDIN RAISSA ARANTES TOBBIN

atrelados à religião, ao matrimônio, à monogamia, à procriação e à perpetuação da espécie humana.

Por muito tempo, os indivíduos que se distanciavam desses padrões de comportamento eram excluídos, considerados impuros, hereges, distantes do sagrado e condenados ao inferno. Ainda, a sexualidade tida como "anormal" e as diversas possibilidades de identidade de gênero e de orientação sexual foram tratadas sob o viés patologizante. Dessa forma, são recentes as contribuições acadêmicas e científicas voltadas para a aceitação e para a compreensão da sexualidade e do gênero como marcadores e reprodutores dos ditames sociais dominantes. Hodiernamente, tem-se que esses conceitos estão em constante desconstrução e construção social. Além disso, como lecionam Rodrigues e Alvarenga, o termo gênero atualmente é utilizado “numa acepção cultural e social, buscando afastar um determinismo biológico".

No entender de Costa, a sexualidade é um conjunto de fenômenos da vida sexual. É o aspecto central da personalidade e é por meio dela que o indivíduo se relaciona com os outros, ama, obtém prazer e se reproduz. Para o autor, é por volta dos cinco ou seis anos que a sexualidade é latente em relação à futura orientação sexual, e é na adolescente que esta se explicitará ${ }^{2}$. Como acentua Ribeiro, para Freud, a manifestação da sexualidade nas crianças é "vigiada e controlada pelos adultos" que tentam a todo custo "ignorar e/ou reprimir, sob a premissa de que a infância é assexuada ou, na vertente posta esta, de que a infância é uma etapa decisiva e que carece de controle, direcionamento, rumo a um ideal conveniente"3.

Nos termos dos Princípios de Yogyakarta ${ }^{4}$ a orientação sexual é a "profunda atração emocional, afetiva ou sexual por indivíduos de gênero diferente, do mesmo gênero ou de mais

\footnotetext{
1 RODRIGUES, Edwirges Elaine; ALVARENGA, Maria Amália de Figueiredo Pereira. Transexualidade e dignidade da pessoa humana. In: Revista Eletrônica do Curso de Direito da UFMS, Santa Maria, v. 10, n. 1, p. 72-93, 2015. p. 78. Disponível em: https://periodicos.ufsm.br/revistadireito/article/view/18583. Acesso em: 13 maio 2019.

${ }^{2}$ COSTA, Ronaldo Pamplona da. Os onze sexos: as múltiplas faces da sexualidade humana. 4. ed. São Paulo: Kondo Editora, 2005. p. 7.

3 RIBEIRO, Cláudia Maria. Gênero e sexualidade no cotidiano de processos educativos: "apesar de tanta sombra, apesar de tanto medo". In: MAIO, Eliane Rose; CORREA, Crishna Mirella de Andrade (orgs.). Gênero, direitos e diversidade sexual: trajetórias escolares. Maringá: UEM, 2013. p. 62.

${ }^{4}$ Os Princípios de Yogyakarta foram aprovados em novembro de 2006, em Yogyakarta, na Indonésia, em conferência realizada para a tentativa de coalizão de organismos internacionais "coordenada pela Comissão Internacional de Juristas e o Serviço Internacional de Direitos Humanos. Tal reunião, que contou com especialistas de 29 países, teve o objetivo de desenvolver um conjunto de princípios jurídicos internacionais sobre a aplicação da legislação internacional às violações de direitos humanos baseadas na orientação sexual e identidade de gênero, com intuito de dar mais clareza e coerência às obrigações de direitos humanos dos Estados no tocante a essa temática. Ao fim dessa conferência, foi aprovada uma carta de princípios sobre a aplicação da legislação internacional de direitos humanos em relação à orientação sexual e identidade de gểnero". In: CAYE, Daniel Paulo; MARQUES, Cláudia Lima. Os Princípios de Yogyakarta e sua interação com o Direito Interno e Políticas Públicas no Brasil. In: SALÃO DE INICIAÇÃO
} 
ISSN 1981-3694

(DOI): $10.5902 / 1981369438872$

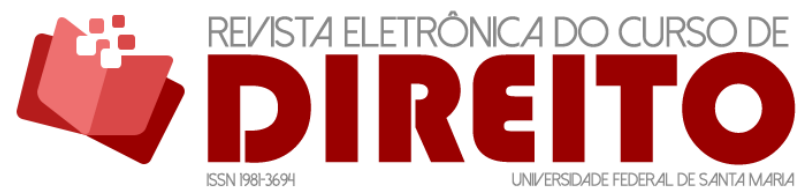

DAS CONSEQUÊNCIAS DA DEMONIZAÇÃO DA PLURALIDADE NAS ESCOLAS À LUZ DO ESTATUTO DA DIVERSIDADE SEXUAL E DE

GÊNERO

VALERIA SILVA GALDINO CARDIN RAISSA ARANTES TOBBIN

de um gênero, assim como ter relações íntimas e sexuais com essas pessoas". Ainda, a identidade de gênero é a "experiência interna e individual do gênero de cada pessoa, que pode ou não corresponder ao sexo atribuído no nascimento, incluindo o senso pessoal do corpo" (que pode envolver, por livre escolha, "modificação da aparência ou função corporal por meios médicos, cirúrgicos ou outros e outras expressões de gênero, inclusive vestimenta, modo de falar e maneirismos”). Conforme o Princípio $3^{\circ}$ do documento, a orientação sexual e a identidade de gênero autodefinidas “constituem parte essencial de sua personalidade e um dos aspectos mais básicos de sua autodeterminação, dignidade e liberdade" 5 .

Para Vieira e Sampaio, a personalidade deriva de "persona, caráter, pessoa, indivíduo", e é um conjunto de características permanentes que tornam o indivíduo único nos planos físico, intelectual e moral ${ }^{6}$. Atualmente, o ideário de proteção da diversidade sexual e de gênero é lastreado pelo sistema internacional de tutela dos direitos humanos. Proclama o artigo $1^{\circ}$ da Declaração Universal dos Direitos Humanos (1948) que “todos os seres humanos nascem livres e iguais em dignidade e em direitos. Dotados de razão e de consciência, devem agir uns para com os outros em espírito de fraternidade". Para Cazelatto e Cardin, os direitos humanos prescrevem que todos os indivíduos são detentores de direitos pela única razão de serem humanos. Logo, "são irrelevantes as distinções relacionadas à raça, ao sexo, à cor da pele, à religião, à condição sexual, ou ao fato de ser portador de deficiência"7. Como compreendem Piovesan e Silva, a ética dos direitos humanos é a ética que vê no outro um ser "dotado do direito de desenvolver as potencialidades humanas de forma livre, autônoma e plena. É a ética orientada pela afirmação da dignidade e pela prevenção ao sofrimento humano"8.

Os autores destacam o fenômeno de universalização dos direitos humanos, que permitiu a criação de um sistema internacional de proteção. Tal sistema é integrado por tratados e CIENTÍFICA PUCRS, 10., 2009. Anais [...]. 2009. p. 2675. Diponível em: http://www.pucrs.br/edipucrs/XSalaolC/Ciencias_Sociais_Aplicadas/Direito/70358-

DANIEL_PAULO_CAYE.pdf. Acesso em: 3 maio 2020.

5 PRINCÍPIOS DE YOGYAKARTA. Princípios sobre a aplicação da legislação internacional de direitos humanos em relação à orientação sexual e identidade de gênero. 2006. Disponível em: www.clam.org.br/uploads/conteudo/principios_de_yogyakarta.pdf. Acesso em: 30 maio 2019. p. 7.

6 VIEIRA, Tereza Rodrigues; SAMPAIO, Liliana Lopes Pedral. Personalidade, identidade civil e autorreconhecimento: consequências psicológicas causadas por um prenome indesejado. In: MIRANDA, José Eduardo; CARDIN, Valéria Silva Galdino. (orgs.). Direitos da personalidade: reconhecimento, garantias e perspectivas. Curitiba: Juruá, 2018. p. 105-120. p. 206.

${ }^{7}$ CAZELATTO, Caio Eduardo Costa; CARDIN, Valéria Silva Galdino. 0 discurso de ódio e minorias sexuais. Rio de Janeiro: Lumen Juris, 2018.

8 PIOVESAN, Flávia; SILVA, Roberto B. Dias da. Igualdade e diferença: o direito à livre orientação sexual na Corte Europeia de Direito Humanos e no Judiciário brasileiro. In: BUGLIONE, Samantha; VENTURA, Miriam. (orgs.). Direito à reprodução e à sexualidade: uma questão de ética e justiça. Rio de Janeiro: Lumen Juris, 2010. p. 65-105. p. 65. 
ISSN 1981-3694

(DOI): $10.5902 / 1981369438872$

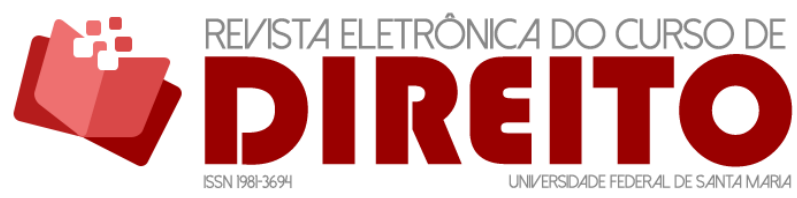

DAS CONSEQUÊNCIAS DA DEMONIZAÇÃO DA PLURALIDADE NAS ESCOLAS À LUZ DO ESTATUTO DA DIVERSIDADE SEXUAL E DE

GÊNERO

VALERIA SILVA GALDINO CARDIN RAISSA ARANTES TOBBIN

convenções que refletem a consciência ética contemporânea, que é compartilhada pelo Estados e compreende um consenso internacional acerca de assuntos centrais para a humanidade, com o escopo de garantir parâmetros protetivos mínimos ${ }^{9}$.

Um documento que se destaca no cenário mundial quanto à proteção dos direitos humanos e dos direitos sexuais e reprodutivos é o Relatório da Conferência Internacional de População e Desenvolvimento (CIPD), realizada no Cairo, em 1994, que representou uma mudança substancial na discussão das questões populacionais e de políticas públicas ligadas à sexualidade, que até então eram voltadas ao controle do crescimento populacional. $\mathrm{Na}$ oportunidade, restou consagrada a saúde e os direitos reprodutivos como valores em si, isto é, variáveis estratégicas do desenvolvimento da cidadania e dos direitos humanos ${ }^{10}$. Conforme o §7.3 da Plataforma do Cairo, os direitos reprodutivos abrangem a garantia básica “de todo casal e de todo indivíduo de decidir livre e responsavelmente sobre o número, o espaçamento e a oportunidade de ter filhos" e de "ter a informação e os meios de assim o fazer, e o direito de gozar do mais elevado padrão de saúde sexual e reprodutiva. Inclui também seu direito de tomar decisões sobre a reprodução, livre de discriminação, coerção ou violência"11.

No Brasil, a Constituição Federal de 1988 representou um grande marco para a proteção da diversidade sexual. Conforme o artigo $1^{\circ}$, inciso III, da Carta Magna, a República Federativa do Brasil, constituída sob a égide de um Estado Democrático de Direito, tem como um dos seus fundamentos "a dignidade da pessoa humana". Também constituem objetivos fundamentais da República Federativa do Brasil, de acordo com os incisos I, III e IV, construir uma sociedade livre, justa e igualitária; erradicar a pobreza e a marginalização e reduzir as desigualdades sociais e regionais; promover o bem de todos, sem preconceitos de origem, raça, sexo, cor, idade e quaisquer outras formas de discriminação ${ }^{12}$. Além disso, segundo o artigo $4^{\circ}$, inciso II, do texto constitucional, o Brasil, em suas relações internacionais, é regido pela "prevalência dos direitos humanos". Ainda, nos termos do artigo $5^{\circ}$ da Constituição, todos são iguais perante a lei, "sem

\footnotetext{
${ }^{9}$ PIOVESAN, Flávia; SILVA, Roberto B. Dias da. Igualdade e diferença: o direito à livre orientação sexual na Corte Europeia de Direito Humanos e no Judiciário brasileiro. In: BUGLIONE, Samantha; VENTURA, Miriam. (orgs.). Direito à reprodução e à sexualidade: uma questão de ética e justiça. Rio de Janeiro: Lumen Juris, 2010. p. 65-105.

${ }^{10}$ ALVES, José Esutáquio Diniz. "O Choque de Civilizações” versus Progressos Civilizatórios. In: CAETANO, André Junqueira; ALVES, José Eustáquio Diniz; CORRÊA, Sônia (orgs.). Dez anos do CAIRO: tendências da fecundidade e direitos reprodutivos no Brasil. Campinas: ABEP, 2004. p. 19-40. p. 34.

11 ALVES, José Esutáquio Diniz. "O Choque de Civilizações" versus Progressos Civilizatórios. In: CAETANO, André Junqueira; ALVES, José Eustáquio Diniz; CORRÊA, Sônia (orgs.). Dez anos do CAIRO: tendências da fecundidade e direitos reprodutivos no Brasil. Campinas: ABEP, 2004. p. 19-40. p. 34.

12 BRASIL. [Constituição (1988)]. Constituição da República Federativa do Brasil de 1988. Brasília, DF: Presidência da República, [2016]. Disponível em:

http://www.planalto.gov.br/ccivil_03/constituicao/constituicao.htm. Acesso em: 1 jan 2017.
} 
ISSN 1981-3694

(DOI): $10.5902 / 1981369438872$

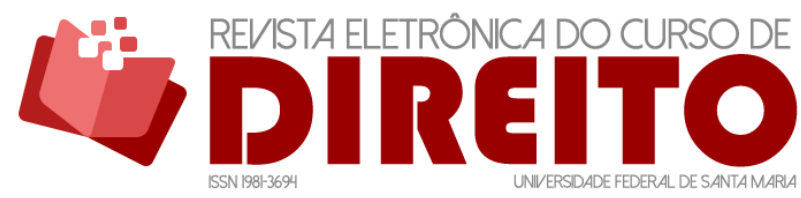

DAS CONSEQUÊNCIAS DA DEMONIZAÇÃO DA PLURALIDADE NAS ESCOLAS À LUZ DO ESTATUTO DA DIVERSIDADE SEXUAL E DE

GÊNERO

VALERIA SILVA GALDINO CARDIN RAISSA ARANTES TOBBIN

distinção de qualquer natureza, garantindo-se aos brasileiros e aos estrangeiros residentes no País a inviolabilidade do direito à vida, à liberdade, à igualdade, à segurança e à propriedade"13.

Conforme previsto no artigo $5^{\circ}$, inciso VI, da Constituição Federal, "é inviolável a liberdade de consciência e de crença, sendo assegurado o livre exercício dos cultos religiosos e garantida, na forma da lei, a proteção aos locais de culto e a suas liturgias". Nos termos do artigo 19, inciso I, da Constituição, é vedado à União, aos Estados, ao Distrito Federal e aos Municípios "estabelecer cultos religiosos ou igrejas, subvencioná-los, embaraçar-lhes o funcionamento ou manter com eles ou seus representantes relações de dependência ou aliança, ressalvada, na forma da lei, a colaboração de interesse público"14. De acordo com Fischmann, o caráter laico do Estado “lhe permite separar-se e distinguir-se das religiões, oferece à esfera pública e à ordem social a possibilidade de convivência da diversidade e da pluralidade humana". Além disso, “permite, também, a cada um dos seus, individualmente, a perspectiva da escolha de ser ou não crente, de associar-se ou não a uma ou outra instituição religiosa". E, "decidindo por crer, ou tendo o apelo para tal, é a laicidade do Estado que garante, a cada um, a própria possibilidade da liberdade de escolher em que e como crer, enquanto é plenamente cidadão, em busca e no esforço de construção da igualdade"15.

A Constituição Federal de 1988 também concedeu tutela especial à família, visto que, conforme o seu artigo 226, esta é a base da sociedade e deve ser protegida pelo Estado. A Carta Magna é considerada um grande marco para o reconhecimento dos direitos dos modelos familiares diversos do tradicionalmente conhecido, composto pela união de um homem com uma mulher e seus filhos, centrada no patriarcado e na submissão da mulher e dos filhos à figura masculina. Com o reconhecimento jurídico das famílias advindas da união estável (art. 226, \$3), a Constituição possibilitou a garantia dos direitos das entidades formadas por casais homossexuais, das famílias monoparentais, anaparentais, multiparentais e socioafetivas.

Para Lôbo, o princípio da liberdade no âmbito do Direito de Família diz respeito ao "poder de escolha ou autonomia de constituição, realização e extinção de entidade familiar; sem imposição ou restrições externas de parentes, da sociedade ou do legislador”. Além disso, tão somente à família cabe o planejamento familiar, a decisão quanto à administração do

13 BRASIL. [Constituição (1988)]. Constituição da República Federativa do Brasil de 1988. Brasília, DF: Presidência da República, [2016]. Disponível em:

http://www.planalto.gov.br/ccivil_03/constituicao/constituicao.htm. Acesso em: 1 jan 2017.

${ }_{14}^{14}$ BRASIL. [Constituição (1988)]. Constituição da República Federativa do Brasil de 1988. Brasília, DF: Presidência da República, [2016]. Disponível em:

http://www.planalto.gov.br/ccivil_03/constituicao/constituicao.htm. Acesso em: 1 jan 2017.

${ }^{15}$ FISCHMANN, Roseli. Estado Laico, Educação, Tolerância e Cidadania ou simplesmente não crer. São Paulo: Factash, 2012. p. 16. 
ISSN 1981-3694

(DOI): $10.5902 / 1981369438872$

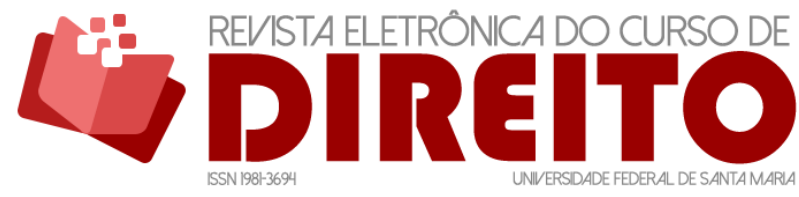

DAS CONSEQUÊNCIAS DA DEMONIZAÇÃO DA PLURALIDADE NAS ESCOLAS À LUZ DO ESTATUTO DA DIVERSIDADE SEXUAL E DE

GÊNERO

VALERIA SILVA GALDINO CARDIN RAISSA ARANTES TOBBIN

patrimônio, a definição do modelo educacional e de formação dos filhos e dos valores religiosos, desde que respeitada a dignidade humana, a liberdade e a integridade física, mental e moral ${ }^{16}$.

Hodiernamente, como vislumbra Diniz, a família é baseada nas concepções de convivência, companheirismo, afeto e amor ${ }^{17}$. Em relação às minorias sexuais, entretanto, escassos ainda são os dispositivos legais que thes concedem direitos antes apenas ofertados aos que se enquadram na ótica cis-hetero-normativa. No Brasil, o que se tem percebido é uma real omissão do Poder Legislativo em aprovar leis que efetivamente protejam tais grupos. Nesse limbo normativo, nos últimos anos, restou ao Poder Judiciário, especialmente ao Supremo Tribunal Federal (STF), a missão de reconhecer os direitos desses indivíduos.

Em 2011, o Supremo Tribunal Federal (STF), em sede do julgamento da Ação Direta de Inconstitucionalidade (ADI) 4277 e da Arguição de Descumprimento de Preceito Fundamental (ADPF) 132, reconheceu a união estável para casais do mesmo sexo, mediante a interpretação conforme a Constituição Federal de 1988 do artigo 1723 do Código Civil ${ }^{18}$. Em março de 2018, durante o julgamento da Ação Direta de Inconstitucionalidade (ADI) 4275, a Corte Superior entendeu ser possível a alteração de nome e de gênero nos assentos de Registro Civil das pessoas transsexuais sem a necessidade de realização de procedimento cirúrgico de redesignação sexual ou submissão a tratamento hormonal ou de laudos médicos ou psicológicos. Na ocasião, o STF deu interpretação conforme a Constituição ao artigo 58 da Lei n 6.01/1973. A decisão também possibilitou a averbação diretamente nas serventias dos Cartórios de Registro Civil das Pessoas Naturais, sendo desnecessária a judicialização do pedido. ${ }^{19}$

Em 13 de junho de 2019, o Supremo Tribunal Federal proferiu decisão pela criminalização da homotransfobia. Doze dos onze ministros reconheceram "haver uma demora inconstitucional do Legislativo em tratar do tema". Diante disso, determinaram que a homofobia deve ser punida pela Lei de Racismo (Lei $\left.n^{\circ} 7716 / 89\right)^{20}$. Apesar das conquistas no âmbito jurídico, destaca-se que, conforme dados da ONG Transgender Europe, o Brasil lidera o ranking dos países que mais mata transexuais no mundo. Entre $1^{\circ}$ de outubro de 2017 e 30 de setembro

\footnotetext{
${ }^{16}$ LÔBO, Paulo. Direito de Família e os princípios constitucionais. In: Tratado de Direito das Famílias. 2. ed. Belo Horizonte: IBDFam, 2016. p. 103-131. p. 118.

17 DINIZ, Maria Helena. Curso de Direito Civil brasileiro: Direito de Família. 24. ed. São Paulo: Saraiva, 2009.

18 SUPREMO reconhece união homoafetiva. NOTíCIAS STF, 5 maio 2011. Disponível em: http:// www.stf.jus.br/portal/cms/verNoticiaDetalhe.asp?idConteudo=178931. Acesso em: 28 maio 2019.

${ }^{19}$ STF reconhece a transgêneros possibilidade de alteração de registro civil sem mudança de sexo. Notícias STF, 1 mar 2018. Disponível em:

http://www.stf.jus.br/portal/cms/verNoticiaDetalhe.asp?idConteudo=371085. Acesso em: 28 maio 2019. 20 BARIFOUSE, Rafael. STF aprova a criminalização da homofobia. BBC News Brasil, São Paulo, 13 jun. 2019. Disponível em: https://www.bbc.com/portuguese/brasil-47206924. Acesso em: 14 jun 2019.
} 
ISSN 1981-3694

(DOI): $10.5902 / 1981369438872$

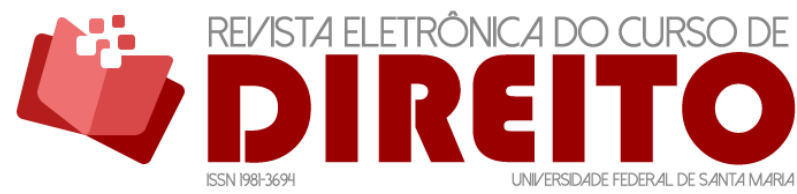

DAS CONSEQUÊNCIAS DA DEMONIZAÇÃO DA PLURALIDADE NAS

ESCOLAS À LUZ DO ESTATUTO DA DIVERSIDADE SEXUAL E DE

GÊNERO

VALERIA SILVA GALDINO CARDIN RAISSA ARANTES TOBBIN

de 2018, 167 transexuais foram mortos no país. Em 2016, foram contabilizadas 136 mortes e em 2017, 171 mortes $^{21}$.

De acordo com Cazellato e Cardin, apesar das conquistas no campo nacional e internacional, "a homofobia continua sendo um dos fatores que mais violam direitos fundamentais e de personalidade de minorias sexuais no Brasil"22. Tal contexto evidencia que a discriminação e o preconceito são problemas sociais brasileiros e que atentam contra os preceitos previstos nos principais instrumentos internacionais de proteção dos direitos humanos e da Constituição Federal de 1988. Diante disso, a investigação de tais circunstâncias passa, obrigatoriamente, pelo território do saber e da educação, capaz de informar, transmitir conhecimento e propor reflexões éticas quanto à temática.

Uma vez que a sexualidade se manifesta desde a mais tenra idade e que a personalidade do indivíduo e a sua identidade de gênero são formadas desde a infância, aflorando na adolescência, é fundamental examinar qual é o papel da escola diante dessas indagações. Nesse sentido, questiona-se: a escola deve instruir quanto ao gênero e à sexualidade? Como não transgredir as concepções familiares e religiosas nem se tornar escrava delas? 0 ensino de gênero nas escolas é um erro ou um acerto? A escola está realmente preparada para lidar com a diversidade? Para o deslinde de tal problemática, inicialmente, é fundamental a análise do direito à educação de gênero, tema do próximo tópico.

\section{A EDUCAÇÃO DE GÊNERO NAS ESCOLAS}

Como já demonstrado, são recentes os estudos e a abordagem da diversidade sexual e de gênero desconexa de concepções patológicas, da religião, da rebeldia e da repulsa social. Logo, também é contemporânea a ideia de um direito à educação de gênero ou da sua essencialidade para o desenvolvimento do indivíduo e para a evolução social diante do combate ao preconceito e à discriminação. Historicamente, a escola não deixa de ser um ambiente reprodutor dos ditames e das concepções sociais e culturais de um povo. Inúmeras vezes também foi local de segregação e de marginalização das pessoas que se distanciavam do padrão hetero-cis-normativo. Uma das grandes barreiras para a ascensão social desses indivíduos é a da

\footnotetext{
${ }^{21}$ QUEIROGA, Louise. Brasil segue no primeiro lugar do ranking de assassinatos de transexuais. 0 Globo, 14 nov. 2018. Disponível em: https://oglobo.globo.com/sociedade/brasil-segue-no-primeiro-lugar-doranking-de-assassinatos-de-transexuais-23234780. Acesso em: 29 maio 2019.

${ }^{22}$ CAZELATTO, Caio Eduardo Costa; CARDIN, Valéria Silva Galdino. 0 discurso de ódio e minorias sexuais. Rio de Janeiro: Lumen Juris, 2018. p. 71.
} 
ISSN 1981-3694

(DOI): $10.5902 / 1981369438872$

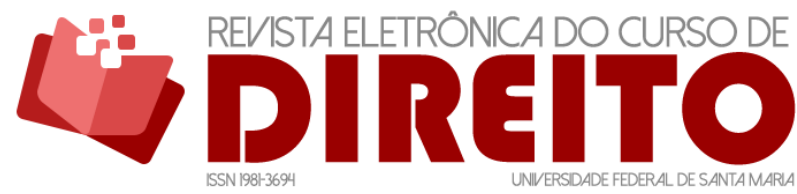

DAS CONSEQUÊNCIAS DA DEMONIZAÇÃO DA PLURALIDADE NAS ESCOLAS À LUZ DO ESTATUTO DA DIVERSIDADE SEXUAL E DE

GÊNERO

VALERIA SILVA GALDINO CARDIN RAISSA ARANTES TOBBIN

educação, visto que muitos não concluíram os níveis da educação básica ou não tiveram a oportunidade de frequentar uma universidade.

No caso da comunidade LGBTQI+, é comum que as dificuldades se iniciem já no seio familiar, a partir do momento em que o comportamento do filho passa a destoar dos padrões comunitários e religiosos. Ou seja, por vezes, a primeira educação, a transmissão de valores, de afeto e de respeito, que vem da família, também é fortemente comprometida pela não aceitação da diversidade. De igual modo, em muitos lares ainda impera o modelo de família patriarcal, em que a submissão feminina ao homem é a palavra de ordem. Nesse sentido, visualiza-se que os conflitos relacionados ao gênero se iniciam no próprio contexto familiar e, por vezes, não são, infelizmente ou felizmente, por ele controlados. Assim, chegam à escola crianças marcadas pela hegemonia de regras sociais a serem cumpridas, e é ingênuo pensar que estas não possuem questionamentos, não percebem seu ambiente familiar de forma crítica ou que não gostariam de receber aconselhamento em certas áreas. Mais do que isso, não raro a escola é a única instituição que pode propiciar condições de rompimento com a lógica opressora familiar $^{23}$. E é por essa abordagem que esse trabalho inicia a defesa da educação de gênero.

Nos termos do artigo 26 da Declaração Universal dos Direitos Humanos, "toda a pessoa tem direito à educação" e, além disso, “a educação deve visar à plena expansão da personalidade humana e ao reforço dos direitos do homem e das liberdades fundamentais" 24 . De acordo com o artigo $6^{\circ}$ da Constituição Federal de 1988, a educação é um direito social e, nos termos do artigo 205 da Carta Magna, é um dever do Estado e da família, devendo ser "promovida e incentivada com a colaboração da sociedade, visando ao pleno desenvolvimento da pessoa, seu preparo para o exercício da cidadania e sua qualificação para o trabalho"25.

Segundo o artigo 206 da Carta Magna, o ensino será ministrado com base: I - na igualdade de condições para o acesso e permanência na escola; II - na liberdade de aprender, ensinar, pesquisar e divulgar o pensamento, a arte e o saber; III - no pluralismo de ideias e de concepções pedagógicas, e coexistência de instituições públicas e privadas de ensino, entre outros $^{26}$. 0 direito à educação também é contemplado pelo Princípio 16 de Yogyakarta, que

${ }^{23}$ CAZELATTO, Caio Eduardo Costa; CARDIN, Valéria Silva Galdino. O discurso de ódio e minorias sexuais. Rio de Janeiro: Lumen Juris, 2018.

24 UNITED NATIONS (ONU). Universal Declaration of Human Rights. 1948. Disponível em: https://www.ohchr.org/EN/UDHR/Pages/Language.aspx?LangID=por. Acesso em: 30 maio 2019.

${ }^{25}$ BRASIL. [Constituição (1988)]. Constituição da República Federativa do Brasil de 1988. Brasília, DF: Presidência da República, [2016]. Disponível em:

http://www.planalto.gov.br/ccivil_03/constituicao/constituicao.htm. Acesso em: 1 jan 2017.

${ }^{26}$ BRASIL. [Constituição (1988)]. Constituição da República Federativa do Brasil de 1988. Brasília, DF: Presidência da República, [2016]. Disponível em: 
ISSN 1981-3694

(DOI): $10.5902 / 1981369438872$

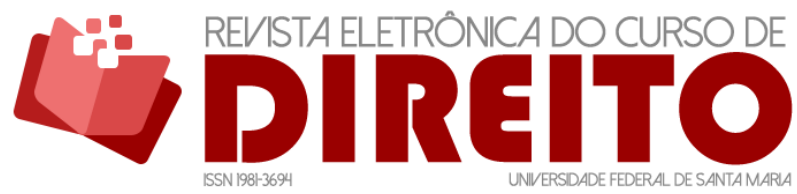

DAS CONSEQUÊNCIAS DA DEMONIZAÇÃO DA PLURALIDADE NAS ESCOLAS À LUZ DO ESTATUTO DA DIVERSIDADE SEXUAL E DE

GÊNERO

VALERIA SILVA GALDINO CARDIN RAISSA ARANTES TOBBIN

preceitua que "toda pessoa tem o direito à educação, sem discriminação por motivo de sua orientação sexual e identidade de gênero, e respeitando essas características”. Assim, conforme o documento, os Estados devem "tomar todas as medidas legislativas, administrativas e outras medidas necessárias para assegurar o acesso igual à educação e o tratamento igual dos e das estudantes, funcionários/as e professores/as no sistema educacional, sem discriminação por motivo de orientação sexual ou identidade de gênero"27.

Consoante 0 artigo $1^{\circ}$ da Lei de Diretrizes e Bases da Educação Nacional (Lei $\mathrm{n}^{\circ}$ 9.394/1996), a educação abrange “os processos formativos que se desenvolvem na vida familiar, na convivência humana, no trabalho, nas instituições de ensino e pesquisa, nos movimentos sociais e organizações da sociedade civil e nas manifestações culturais"28. Segundo o artigo $3^{\circ}$, incisos II, III e IV, dessa Lei, o ensino será ministrado com base na liberdade de aprender, de ensinar, de pesquisar e de divulgar a cultura, o pensamento, a arte e o saber; o pluralismo de ideias e de concepções pedagógicas e o respeito à liberdade e o apreço à tolerância ${ }^{29}$.

Outro documento oficial fundamental para a Educação brasileira é o composto pelos Parâmetros Curriculares Nacionais (PCNs), que prescrevem que, em uma sociedade democrática, “o processo educacional não pode ser instrumento para a imposição, por parte do governo, de um projeto de sociedade e de nação”. Pelo contrário, o projeto educacional necessita ser pela “contraposição de diferentes interesses e a negociação política necessária para encontrar soluções para os conflitos sociais". Nos termos dos PCNs, cabe à escola propiciar aos alunos as capacidades necessárias para a inserção sociopolítica e cultural. Para isso, precisa ser um espaço de construção de significados éticos e constitutivos de cidadania, ambiente de "formação e informação, em que a aprendizagem de conteúdos deve necessariamente favorecer a inserção do aluno no dia a dia das questões sociais marcantes e em um universo cultural maior"30.

http://www.planalto.gov.br/ccivil_03/constituicao/constituicao.htm. Acesso em: 1 jan 2017.

27 PRINCÍPIOS DE YOGYAKARTA. Princípios sobre a aplicação da legislação internacional de direitos humanos em relação à orientação sexual e identidade de gênero. 2006. Disponível em: www.clam.org.br/uploads/conteudo/principios_de_yogyakarta.pdf. Acesso em: 30 maio 2019.

${ }_{28}$ BRASIL. Lei $\mathrm{n}^{\circ}$ 9.394, de 20 de dezembro de 1996. Estabelece as diretrizes e bases da educação nacional. Brasília, DF: Presidência da República, [2019]. Disponível em: http://www.planalto.gov.br/ccivil_03/leis/19394.htm. Acesso em: 30 maio 2019.

29 BRASIL. Lei $n^{\circ}$ 9.394, de 20 de dezembro de 1996. Estabelece as diretrizes e bases da educação nacional. Brasília, DF: Presidência da República, [2019]. Disponível em: http://www.planalto.gov.br/ccivil_03/leis/l9394.htm. Acesso em: 30 maio 2019.

30 BRASIL. Secretaria de Educação Fundamental. Parâmetros curriculares nacionais: introdução aos parâmetros curriculares nacionais. Brasília, DF: MEC/SEF, 1997. p. 27. Disponível em: http://portal.mec.gov.br/seb/arquivos/pdf/livro01.pdf. Acesso em: 30 maio 2019. 
ISSN 1981-3694

(DOI): $10.5902 / 1981369438872$

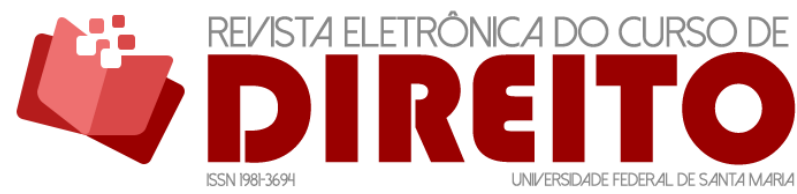

DAS CONSEQUÊNCIAS DA DEMONIZAÇÃO DA PLURALIDADE NAS ESCOLAS À LUZ DO ESTATUTO DA DIVERSIDADE SEXUAL E DE

GÊNERO

VALERIA SILVA GALDINO CARDIN RAISSA ARANTES TOBBIN

Os PCNs, além de proclamarem parâmetros educacionais gerais, abordam certos temas específicos, chamados pelo documento de "transversais", e são eles: a ética, a saúde, o meio ambiente, a orientação sexual e a pluralidade cultural. Em relação à sexualidade, os Parâmetros Curriculares reconhecem que as manifestações desta afloram em todas as faixas etárias e compreendem que ignorar, reprimir e ocultar tal contexto são respostas habituais dadas por profissionais do âmbito educacional, que se baseiam na ideia de que a sexualidade é assunto que deve ser abordado apenas pela família ${ }^{31}$.

O documento reconhece que é a família que inicia a educação sexual de crianças e adolescentes, mesmo aquelas que não discutem o assunto abertamente. Logo, o cenário familiar de valores conservadores, liberais ou progressistas, a religião e a fé professada são fatores determinantes da educação dos infantes. Pode-se afirmar que "é no espaço privado, portanto, que a criança recebe com maior intensidade as noções a partir das quais vai construindo e expressando a sua sexualidade" ${ }^{32}$. Ainda, para os PCNs, a construção do que é pertencer a um ou outro sexo "se dá pelo tratamento diferenciado para meninos e meninas, inclusive nas expressões diretamente ligadas à sexualidade, e pelos padrões socialmente estabelecidos de feminino e masculino". Esses padrões são oriundos "das representações sociais e culturais construídas a partir das diferenças biológicas dos sexos, e transmitidas através da educação, o que atualmente recebe a denominação de 'relações de gênero'”33.

Por outro lado, os PCNs também visualizam que a sexualidade não é tema que se esgota no seio familiar, pelo contrário, “ela 'invade' a escola por meio das atitudes dos alunos em sala de aula e da convivência social entre eles". Dessa forma, "queira ou não, a escola intervém de várias formas, embora nem sempre tenha consciência disso e nem sempre acolha as questões dos adolescentes e jovens". Seja no cotidiano da sala de aula, "quando proíbe certas manifestações e permite outras, seja quando opta por informar os pais sobre manifestações de seu filho, a

31 BRASIL. Secretaria de Educação Fundamental. Parâmetros curriculares nacionais: introdução aos parâmetros curriculares nacionais. Brasília, DF: MEC/SEF, 1997. p. 291. Disponível em: http://portal.mec.gov.br/seb/arquivos/pdf/livro01.pdf. Acesso em: 30 maio 2019.

32 BRASIL. Secretaria de Educação Fundamental. Parâmetros curriculares nacionais: introdução aos parâmetros curriculares nacionais. Brasília, DF: MEC/SEF, 1997. p. 291. Disponível em: http://portal.mec.gov.br/seb/arquivos/pdf/livro01.pdf. Acesso em: 30 maio 2019.

33 BRASIL. Secretaria de Educação Fundamental. Parâmetros curriculares nacionais: introdução aos parâmetros curriculares nacionais. Brasília, DF: MEC/SEF, 1997. p. 295. Disponível em: http://portal.mec.gov.br/seb/arquivos/pdf/livro01.pdf. Acesso em: 30 maio 2019. 
ISSN 1981-3694

(DOI): 10.5902/1981369438872

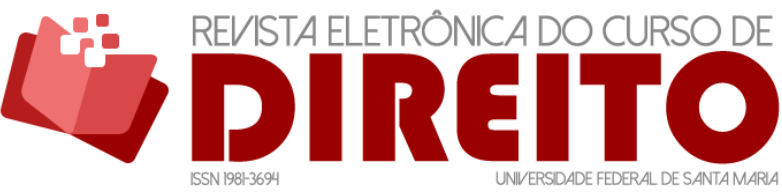

DAS CONSEQUÊNCIAS DA DEMONIZACCÃO DA PLURALIDADE NAS

escola está sempre transmitindo certos valores, mais ou menos rígidos", a depender dos profissionais envolvidos no momento ${ }^{34}$.

Como pontua Ribeiro, a escola tem por tendência "perpetuar as condições sociais sobre o que vem a ser sexualidade, de como, onde e quando manifestá-la", uma vez que "os tempos e espaços da escola são enquadrados nos moldes que sempre vêm ao encontro do imaginário social e de seus códigos morais" ${ }^{35}$. Logo, para os PCNs, não cabe a escola ditar regras ou estabelecer padrões do que é certo ou errado em relação à sexualidade. Cabe a ela desenvolver o diálogo crítico, reflexivo e educativo, o que deve fazer por meio da exposição dos diversos pontos de vista, valores e crenças sociais, que auxiliam o aluno na construção de suas referências e de ação refletiva. 0 trabalho realizado pela escola não substitui nem concorre com a função da família, apenas a complementa. ${ }^{36}$ Como o próprio documento prescreve:

A Orientação Sexual aqui proposta não pretende ser diretiva e está circunscrita ao âmbito pedagógico e coletivo, não tendo, portanto, caráter de aconselhamento individual nem psicoterapêutico. Isso quer dizer que as diferentes temáticas da sexualidade devem ser trabalhadas dentro do limite da ação pedagógica, sem invadir a intimidade e o comportamento de cada aluno ou professor. Tal postura deve, inclusive, auxiliar as crianças e os jovens a discriminar o que pode e deve ser compartilhado no grupo e o que deve ser mantido como vivência pessoal. Apenas os alunos que, por questões pessoais, demandem atenção e intervenção individuais, devem ser atendidos separadamente do grupo pelo professor ou orientador na escola, e poderá ser discutido um possível encaminhamento para atendimento especializado ${ }^{37}$.

Essa perspectiva ganha relevo diante da constatação da curiosidade das crianças e adolescentes acerca de questões significativas e subjetivas, especialmente as voltadas para a área sexual. Dessa forma, a satisfação dessa curiosidade contribui para que "o desejo de saber seja impulsionado ao longo da vida, enquanto a não-satisfação gera ansiedade, tensão e,

\footnotetext{
34 BRASIL. Secretaria de Educação Fundamental. Parâmetros curriculares nacionais: introdução aos parâmetros curriculares nacionais. Brasília, DF: MEC/SEF, 1997. p. 292. Disponível em: http://portal.mec.gov.br/seb/arquivos/pdf/livro01.pdf. Acesso em: 30 maio 2019.

35 RIBEIRO, Cláudia Maria. Gênero e sexualidade no cotidiano de processos educativos: "apesar de tanta sombra, apesar de tanto medo". In: MAIO, Eliane Rose; CORREA, Crishna Mirella de Andrade (orgs.). Gênero, direitos e diversidade sexual: trajetórias escolares. Maringá: UEM, 2013. p. 63.

36 BRASIL. Secretaria de Educação Fundamental. Parâmetros curriculares nacionais: introdução aos parâmetros curriculares nacionais. Brasília, DF: MEC/SEF, 1997. Disponível em: http://portal.mec.gov.br/seb/arquivos/pdf/livro01.pdf. Acesso em: 30 maio 2019.

37 BRASIL. Secretaria de Educação Fundamental. Parâmetros curriculares nacionais: introdução aos parâmetros curriculares nacionais. Brasília, DF: MEC/SEF, 1997. p. 300. Disponível em: http://portal.mec.gov.br/seb/arquivos/pdf/livro01.pdf. Acesso em: 30 maio 2019.
} 
ISSN 1981-3694

(DOI): $10.5902 / 1981369438872$

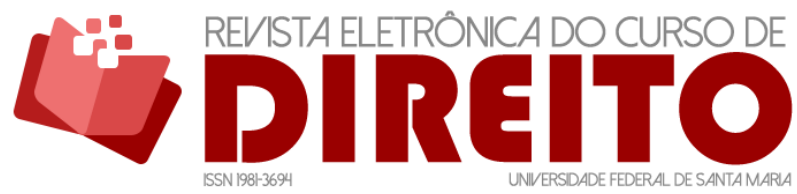

DAS CONSEQUÊNCIAS DA DEMONIZAÇÃO DA PLURALIDADE NAS ESCOLAS À LUZ DO ESTATUTO DA DIVERSIDADE SEXUAL E DE

GÊNERO

VALERIA SILVA GALDINO CARDIN RAISSA ARANTES TOBBIN

eventualmente, inibição da capacidade investigativa"38. Os Parâmetros também se atentam para a promoção da saúde das crianças e para a prevenção de doenças sexualmente transmissíveis, já que pontuam que é necessário um trabalho contínuo da escola quanto a essas questões, uma vez que diversos estudos já demonstraram "os parcos resultados obtidos por trabalhos esporádicos sobre esse assunto. Ainda, inúmeras pesquisas apontam também que "apenas a informação não é suficiente para favorecer a adoção de comportamentos preventivos". ${ }^{39}$

Para os PCNs, a orientação sexual na escola contribui para o conhecimento e a valorização dos direitos reprodutivos, bem como para a possibilidade de que homens e mulheres “tomem decisões sobre sua fertilidade, saúde reprodutiva e criação de filhos, tendo acesso às informações e aos recursos necessários para implementar suas decisões" ${ }^{40}$, uma vez que o corpo, como sede do ser, "é uma fonte inesgotável de questões e debates, que vão muito além do que é habitual incluir nos estudos da sua anatomia e fisiologia" ${ }^{41}$. Para o documento, a sexualidade é fundamental para o desenvolvimento do indivíduo e de sua potencialidade reprodutiva. Além disso, relaciona-se com a busca do prazer, uma necessidade fundamental dos seres humanos e que está lastreada "pela história, cultura, ciência, assim como pelos afetos e sentimentos, expressando-se então com singularidade em cada sujeito"42.

Logo, a discussão plural e democrática, no ambiente escolar, de questões delicadas e polêmicas, tais como a masturbação; a iniciação sexual; o "ficar" e o namoro; a homossexualidade; o aborto; as disfunções sexuais; a prostituição; e a pornografia, em muito contribui para o bem-estar e a vivência atual e futura das crianças e dos adolescentes. Diante disso, passível é perceber que o trabalho das questões pertinentes à sexualidade na escola exige planejamento e intervenção por parte de profissionais da educação, uma vez que "o trabalho de

38 BRASIL. Secretaria de Educação Fundamental. Parâmetros curriculares nacionais: introdução aos parâmetros curriculares nacionais. Brasília, DF: MEC/SEF, 1997. p. 292. Disponível em: http://portal.mec.gov.br/seb/arquivos/pdf/livro01.pdf. Acesso em: 30 maio 2019.

39 BRASIL. Secretaria de Educação Fundamental. Parâmetros curriculares nacionais: introdução aos parâmetros curriculares nacionais. Brasília, DF: MEC/SEF, 1997. p. 292. Disponível em: http://portal.mec.gov.br/seb/arquivos/pdf/livro01.pdf. Acesso em: 30 maio 2019.

${ }_{40}$ BRASIL. Secretaria de Educação Fundamental. Parâmetros curriculares nacionais: introdução aos parâmetros curriculares nacionais. Brasília, DF: MEC/SEF, 1997. p. 293. Disponível em: http://portal.mec.gov.br/seb/arquivos/pdf/livro01.pdf. Acesso em: 30 maio 2019.

41 BRASIL. Secretaria de Educação Fundamental. Parâmetros curriculares nacionais: introdução aos parâmetros curriculares nacionais. Brasília, DF: MEC/SEF, 1997. p. 321. Disponível em: http://portal.mec.gov.br/seb/arquivos/pdf/livro01.pdf. Acesso em: 30 maio 2019.

42 BRASIL. Secretaria de Educação Fundamental. Parâmetros curriculares nacionais: introdução aos parâmetros curriculares nacionais. Brasília, DF: MEC/SEF, 1997. p. 295. Disponível em: http://portal.mec.gov.br/seb/arquivos/pdf/livro01.pdf. Acesso em: 30 maio 2019. 
ISSN 1981-3694

(DOI): $10.5902 / 1981369438872$

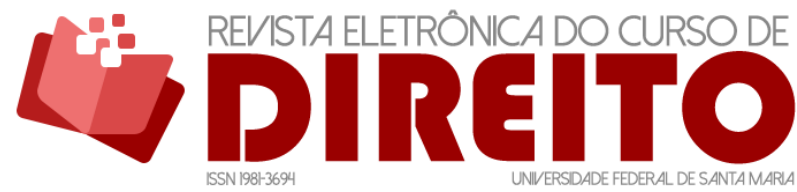

DAS CONSEQUÊNCIAS DA DEMONIZAÇÃO DA PLURALIDADE NAS ESCOLAS À LUZ DO ESTATUTO DA DIVERSIDADE SEXUAL E DE

GÊNERO

VALERIA SILVA GALDINO CARDIN RAISSA ARANTES TOBBIN

Orientação Sexual na escola se faz problematizando, questionando e ampliando o leque de conhecimentos e de opções para que o próprio aluno escolha seu caminho"43.

Logo, não há que se falar em sexualidade na escola sem que o educador tenha formação específica e continuada para tanto, de forma a possibilitar a construção de uma postura profissional consciente. Essencialmente, os professores necessitam também "entrar em contato com suas próprias dificuldades diante do tema, com questões teóricas, leituras e discussões referentes à sexualidade e suas diferentes abordagens; preparar-se para a intervenção prática junto aos alunos", tendo também acesso a “um espaço grupal de produção de conhecimento a partir dessa prática, se possível contando com assessoria especializada" ${ }^{44}$.

Nesse sentido, a postura dos educadores precisa refletir valores democráticos e pluralistas, tendo em vista que "é importante que os educadores reconheçam como legítimas e lícitas, por parte das crianças e dos jovens, a busca do prazer e as curiosidades manifestas acerca da sexualidade”45. Tais concepções, como expõem Reis e Eggert, acompanham o padrão internacionalmente estabelecido de respeito à diversidade e do papel da escola frente a essas esferas temáticas $^{46}$. Especialmente no Brasil, a promoção da educação voltada para o respeito à pluralidade é importante diante dos altos índices de violência e de discriminação que acometem os indivíduos que destoam do modelo tradicional de orientação sexual e de identidade de gênero e que, no presente momento, também são afetados pelas controvérsias e tensões que envolvem a temática da educação de gênero.

\section{A IDEOLOGIA DE GÊNERO E O DISCURSO POLÍTICO}

O termo “ideologia de gênero" é atualmente centro de grandes impasses no campo político e social brasileiro. Ainda muitas são as imprecisões e polêmicas que permeiam tal

\footnotetext{
43 BRASIL. Secretaria de Educação Fundamental. Parâmetros curriculares nacionais: introdução aos parâmetros curriculares nacionais. Brasília, DF: MEC/SEF, 1997. p. 300. Disponível em: http://portal.mec.gov.br/seb/arquivos/pdf/livro01.pdf. Acesso em: 30 maio 2019.

44 BRASIL. Secretaria de Educação Fundamental. Parâmetros curriculares nacionais: introdução aos parâmetros curriculares nacionais. Brasília, DF: MEC/SEF, 1997. p. 303. Disponível em: http://portal.mec.gov.br/seb/arquivos/pdf/livro01.pdf. Acesso em: 30 maio 2019.

45 BRASIL. Secretaria de Educação Fundamental. Parâmetros curriculares nacionais: introdução aos parâmetros curriculares nacionais. Brasília, DF: MEC/SEF, 1997. p. 302. Disponível em: http://portal.mec.gov.br/seb/arquivos/pdf/livro01.pdf. Acesso em: 30 maio 2019.

46 REIS, Toni; EGGERT, Edla. Ideologia de Gênero: uma falácia construída sobre os planos de educação brasileiros. Educação e Sociedade, Campinas, v. 38, n. 138, p. 9-26, jan./mar. 2017. Disponível em: http://www.scielo.br/pdf/es/v38n138/1678-4626-es-38-138-00009.pdf. Acesso em: 21 maio 2019.
} 
ISSN 1981-3694

(DOI): $10.5902 / 1981369438872$

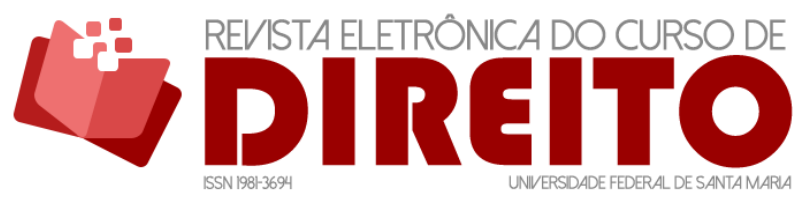

DAS CONSEQUÊNCIAS DA DEMONIZAÇÃO DA PLURALIDADE NAS ESCOLAS À LUZ DO ESTATUTO DA DIVERSIDADE SEXUAL E DE

GÊNERO

VALERIA SILVA GALDINO CARDIN RAISSA ARANTES TOBBIN

cenário, os reais motivos pelos quais esta seria combatida, por quem e quais seriam os seus objetivos. De início, o que se percebe é que essa temática não comporta definições simplistas e pode servir de discurso de manobra política. Em 2011, causou grande controvérsia o material didático do programa "Escola sem Homofobia", apelidado pelos setores mais conservadores de "kit gay", que seria distribuído em seis mil escolas públicas, mas que, depois de forte argumentação contrária, foi vetado pela então presidente Dilma Roussef ${ }^{47}$.

A discussão no que tange à "ideologia de gênero" voltou a ganhar notoriedade quando da discussão no Congresso do Plano Nacional de Ensino, em 2014. A Lei de Diretrizes e Bases da Educação Nacional (LDB) de 1996 estabeleceu a elaboração, pela União, em colaboração com os Estados, os Municípios e o Distrito Federal, de um plano decenal, que estivesse em harmonia com a Declaração Mundial sobre Educação para Todos de 1990. Em cumprimento a tal disposição, o primeiro Plano Nacional da Educação (PNE) foi elaborado e vigorou de 2001 a 2010.

Além disso, é importante ressaltar que o PNE foi instituído pela Constituição Federal de 1988 pela Emenda Constitucional $n^{\circ} 59$ de $2009^{48}$. A proposta de um novo PNE foi apresentada à Câmara dos Deputados em dezembro de 2010 e, após quase dois anos de tramitação e debate, a redação final foi aprovada e seguiu para o Senado, contemplando as deliberações das Conferências Nacionais de Educação acerca da igualdade de gênero e do respeito à diversidade sexual ${ }^{49}$. $\mathrm{O}$ artigo $2^{\circ}$, inciso III, do referido Plano proclamava que eram diretrizes do PNE a superação das desigualdades educacionais, com ênfase para a promoção da igualdade racial, regional, de gênero e de orientação sexual e na erradicação de todas as formas de discriminação. Além disso, a redação do documento utilizava a flexão de gênero, o que demonstrava que este tinha por intenção a igualdade de gênero ${ }^{50}$.

Entretanto, em dezembro de 2013, o Senado aprovou o Substitutivo ao Projeto de Lei, retirando da redação do inciso III, do artigo $2^{\circ}$, a frase "promoção da igualdade racial, regional, de gênero e de orientação sexual". Ainda, suprimiu em toda a redação do texto a flexão de

47 MISKLOCI, Richard; CAMPANA, Maximiliano. "Ideologia de gênero": notas para a genealogia de um pânico moral contemporâneo. Revista Sociedade e Estado, v. 32, n. 3, p. 725-747, set./dez. 2017. Disponível em: http://www.scielo.br/pdf/se/v32n3/0102-6992-se-32-03-725.pdf. Acesso em: 21 maio 2019. p. 738.

${ }^{48}$ MAIA, Marcos Felipe Gonçalves; ROCHA, Damião. Ideologia de Gênero: tensões e desdobramentos na educação. Revista Contemporânea de Educação, v. 12, n. 25, p. 402-419, set./dez. 2017. Disponível em: https://revistas.ufrj.br/index.php/rce/article/view/3690/pdf. Acesso em: 22 maio 2019.

${ }_{49}$ REIS, Toni; EGGERT, Edla. Ideologia de Gênero: uma falácia construída sobre os planos de educação brasileiros. Educação e Sociedade, Campinas, v. 38, n. 138, p. 9-26, jan./mar. 2017. Disponível em: http://www.scielo.br/pdf/es/v38n138/1678-4626-es-38-138-00009.pdf. Acesso em: 21 maio 2019.

50 REIS, Toni; EGGERT, Edla. Ideologia de Gênero: uma falácia construída sobre os planos de educação brasileiros. Educação e Sociedade, Campinas, v. 38, n. 138, p. 9-26, jan./mar. 2017. Disponível em: http://www.scielo.br/pdf/es/v38n138/1678-4626-es-38-138-00009.pdf. Acesso em: 21 maio 2019. 
ISSN 1981-3694

(DOI): $10.5902 / 1981369438872$

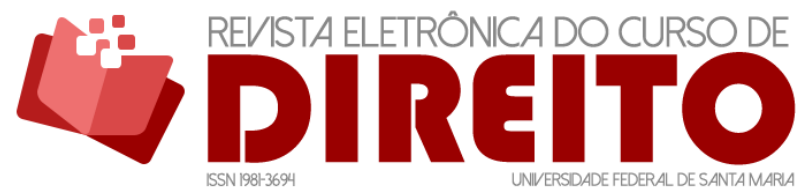

DAS CONSEQUÊNCIAS DA DEMONIZAÇÃO DA PLURALIDADE NAS ESCOLAS À LUZ DO ESTATUTO DA DIVERSIDADE SEXUAL E DE

GÊNERO

VALERIA SILVA GALDINO CARDIN RAISSA ARANTES TOBBIN

gênero. No retorno à Câmara, as audiências em torno do Projeto de Lei foram marcadas pelo debate da "ideologia de gênero", até a sua sanção presidencial, em 25 de junho de 2014, com a flexão de gênero, mas sem a redação original do inciso III do artigo $2^{\circ}$ do $\mathrm{PNE}^{51}$.

Posteriormente, a discussão acerca da “ideologia de gênero" se estendeu aos Planos Municipais e Estaduais de Educação, oportunidades em que o termo foi utilizado por setores tradicionais e fundamentalistas para o combate do que seria “a desconstrução dos papéis tradicionais de gênero do homem e da mulher". Como pontuam Reis e Eggert, nenhum dos Documentos Finais das Conferências de Educação dos anos de 2008, 2010 e 2014 ou a versão inicial do Plano Nacional de Educação fazem menção ao termo “ideologia de gênero", tendo apenas por objetivo a garantia da igualdade entre os gêneros e o respeito à diversidade. Pelo contrário, o termo "ideologia de gênero" foi cunhado pelos próprios setores reacionários que se posicionaram contra a aceitação do PNE em $2014^{52}$.

Para Marcon, Prudêncio e Gesser, atualmente há, de um lado, os movimentos sociais que "lutam pela igualdade de direitos e pela diversidade sexual e, de outro, políticos altamente conservadores que defendem ideais morais e religiosos voltados à patologização das sexualidades" ${ }^{2}$. Para Mariano e Gerardi, uma das consequências da polarização política e de todos os problemas sociais e econômicos enfrentados atualmente pelo país é a consolidação de uma "direita cristã". ${ }^{54}$ As declarações do governo federal eleito em 2018 também não cooperam para que seja reconhecida a importância da ideologia de gênero para o rompimento com os principais modelos segregatórios de gênero e da sexualidade. 0 atual presidente Jair Bolsonaro (PSL) afirmou, ainda durante o período eleitoral, que "quem ensina sexo para a criança é o papai e a mamãe" e não a escola ${ }^{55}$. Ainda, em vídeo altamente propagado em janeiro de 2019, a

\footnotetext{
${ }^{51}$ REIS, Toni; EGGERT, Edla. Ideologia de Gênero: uma falácia construída sobre os planos de educação brasileiros. Educação e Sociedade, Campinas, v. 38, n. 138, p. 9-26, jan./mar. 2017. Disponível em: http://www.scielo.br/pdf/es/v38n138/1678-4626-es-38-138-00009.pdf. Acesso em: 21 maio 2019.

52 REIS, Toni; EGGERT, Edla. Ideologia de Gênero: uma falácia construída sobre os planos de educação brasileiros. Educação e Sociedade, Campinas, v. 38, n. 138, p. 9-26, jan./mar. 2017. Disponível em: http://www.scielo.br/pdf/es/v38n138/1678-4626-es-38-138-00009.pdf. Acesso em: 21 maio 2019.

53 MARCON, Amanda Nogara; PRUDÊNCIO, Luísa Evangelista Vieira; GESSER, Marivete. Políticas públicas relacionadas à diversidade sexual na escola. Revista Psicologia Escolar e Educacional, São Paulo, v. 20, n. 2, p. 291-301, maio/ago. 2016. p. 293. Disponível em: http://www.scielo.br/pdf/pee/v20n2/21753539-pee-20-02-00291.pdf. Acesso em: 29 maio 2019.

${ }^{54}$ MARIANO, Ricardo; GERARDI, Dirceu André. Eleições presidenciais na América Latina em 2018 e ativismo político. Revista USP, n. 120, p. 61-76, jan./mar. 2019. p. 74. Disponível em: https://www.revistas.usp.br/revusp/article/view/155531/151189. Acesso em: 20 jun 2019.

${ }_{55}$ BARONE, Isabelle. Quem ensina sexo para a criança é "o papai e a mamãe" e não a escola, como diz Bolsonaro? Gazeta do Povo, 27 abr. 2019. Disponível em:

https://www.gazetadopovo.com.br/educacao/quem-ensina-sexo-para-a-crianca-e-o-papai-e-a-a-mamaediz-bolsonaro-o-que-dizem-especialistas/ Acesso em: 20 jun 2019.
} 
ISSN 1981-3694

(DOI): $10.5902 / 1981369438872$

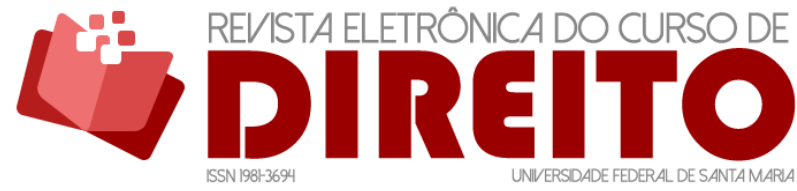

DAS CONSEQUÊNCIAS DA DEMONIZAÇÃO DA PLURALIDADE NAS ESCOLAS À LUZ DO ESTATUTO DA DIVERSIDADE SEXUAL E DE

GÊNERO

VALERIA SILVA GALDINO CARDIN RAISSA ARANTES TOBBIN

Ministra Damares Alves, da pasta da Mulher, Família e Direitos Humanos, afirmou que "menino veste azul e menina veste rosa". A Ministra ainda comemorou que o Brasil viveria uma "nova era". ${ }^{56}$ Posteriormente, a Ministra disse que sua fala era uma crítica à ideologia de gênero.

No entender de Maia e Rocha, é possível perceber na literatura científica a acepção do termo "ideologia de gênero" em quatro nuances: “a ideologia de gênero" como discurso heterossexista; como crítica aos estudos de gênero; como crítica aos papéis sociais de homens e de mulheres; e como antifeminismo". ${ }^{57}$ Como visualiza Xavier, em uma visão tradicional do currículo, "a sexualidade em uma sociedade é homogênea, universal e única. Nessa perspectiva, não há o que problematizar, muito menos visualizar conflitos no processo educacional"58. Por outro lado, como pontua Xavier, na perspectiva crítica do currículo, a sexualidade é percebida como "um terreno conflituoso e de criação simbólica, em que os conhecimentos são construídos e desconstruídos a todo momento". Ainda, "nenhum currículo é elaborado no vazio, nem tão pouco se organiza de forma arbitrária. Tudo é pensado e programado, visando um determinado objetivo dentro de uma lógica e de uma cultura ${ }^{59}$.

Logo, da mesma forma que o currículo com base na aceitação da diversidade possui uma intenção programática, o currículo sustentado pela frente reacionária da "ideologia de gênero" também possui o seu escopo: a perpetuação de padrões e modelos retrógrados e deflagradores de direitos de muitos indivíduos. Nesse ponto, Miskloci e Campana, estudando os conflitos latinoamericanos em torno dos direitos sexuais e reprodutivos e diante da análise do discurso identificado e analisado como "ideologia de gênero", observou certas características e semelhanças: os que empreendem moralmente contra a educação de gênero

não formam um grupo coeso e sua aliança é circunstancial. É em relação (dependente) com o que denominam de "ideologia de gênero" que constroem um espaço político-moral mais ou menos compartilhado por católicos, neopentecostais ou outros grupos e indivíduos que se identificam com ele. 0 campo discursivo de ação contra a temida "ideologia de gênero" tende a ser

\footnotetext{
${ }^{56}$ CERIONI, Clara. Menino veste azul e menina veste rosa, diz Damares em vídeo. Exame, 3 jan. 2019. Disponível em: https: / /exame.abril.com.br/brasil/menino-veste-azul-e-menina-veste-rosa-diz-damares-em-video/.

Acesso em: 20 jun 2019.

${ }^{57}$ MAIA, Marcos Felipe Gonçalves; ROCHA, Damião. Ideologia de Gênero: tensões e desdobramentos na educação. Revista Contemporânea de Educação, v. 12, n. 25, p. 402-419, set./dez. 2017. p. 411. Disponível em: https://revistas.ufrj.br/index.php/rce/article/view/3690/pdf. Acesso em: 22 maio 2019.

58 XAVIER, Gláucia do Carmo. Transexualidade no Ensino Médio: desafios e possibilidades. Cadernos de Gênero e Diversidade, Salvador, v. 5, n. 1, p. 79-95, jan./mar. 2019. p. 85. Disponível em: https://portalseer.ufba.br/index.php/cadgendiv/article/view/31931/18993. Acesso em: 22 maio 2019.

59 XAVIER, Gláucia do Carmo. Transexualidade no Ensino Médio: desafios e possibilidades. Cadernos de Gênero e Diversidade, Salvador, v. 5, n. 1, p. 79-95, jan./mar. 2019. p. 85. Disponível em: https://portalseer.ufba.br/index.php/cadgendiv/article/view/31931/18993. Acesso em: 22 maio 2019.
} 
ISSN 1981-3694

(DOI): $10.5902 / 1981369438872$

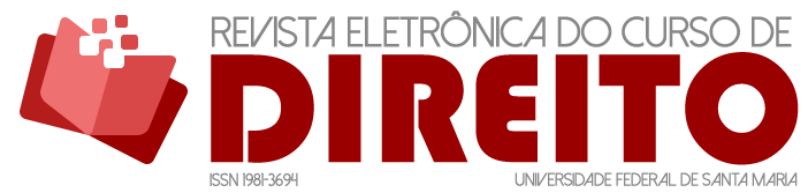

DAS CONSEQUÊNCIAS DA DEMONIZAÇÃO DA PLURALIDADE NAS ESCOLAS À LUZ DO ESTATUTO DA DIVERSIDADE SEXUAL E DE

GÊNERO

VALERIA SILVA GALDINO CARDIN RAISSA ARANTES TOBBIN

reconhecido como politicamente de direita, mas também atrai e agrega um público que - em meio à crise econômica recente e às denúncias de corrupção em diversos países latino-americanos - passa a se afirmar apartidário e/ou insatisfeito com a política institucional ${ }^{60}$.

Os autores também identificaram que a luta contra a "ideologia de gênero também é reacionária à disseminação da agenda feminista por igualdade a partir das concepções propostas pela Conferência de Beijing (1995)", continuação dos trabalhos iniciados na Plataforma do Cairo, em 1994. Para os autores, a ascensão feminina ao poder em contextos com pouca representatividade desta no Legislativo, como ocorreu no Brasil e no Chile, é ambiente propício para a imposição e o enfretamento por parte dos marcadores sociais tradicionais ${ }^{61}$. É importante destacar que muitos dos combatentes da "ideologia de gênero" justificam tal luta diante da garantia do direito à liberdade de expressão, previsto no artigo $5^{\circ}$, inciso IX, da Constituição Federal de 1988, que prescreve que "é livre a expressão da atividade intelectual, artística, científica e de comunicação, independentemente de censura ou licença"62.

Entretanto, como ponderam Cardin, Segatto e Cazelatto, apesar de sua grande valorização, o direito à liberdade de expressão não é absoluto e comporta restrições. Isso porque "a liberdade de deixar tudo fazer, o laisser faire incondicional, pode ocasionar violações brutais de direitos humanos básicos". É o que acontece com a "propagação de ideologias que desrespeitem e lesem direitos de terceiros, especialmente os de minorias sociais, potencializando suas vulnerabilidades". ${ }^{63}$ Dessa forma, "toda conduta que ultrapassa os limites da esfera da autodeterminação poderá ser utilizada como instrumento de repressão"64.

Assim, o que se apreende das principais polêmicas em torno da “ideologia de gênero" é que esse termo é utilizado por setores de oposição à igualdade de gênero e à aceitação da

60 MISKLOCI, Richard; CAMPANA, Maximiliano. “Ideologia de gênero": notas para a genealogia de um pânico moral contemporâneo. Revista Sociedade e Estado, v. 32, n. 3, p. 725-747, set./dez. 2017. p. 742. Disponível em: http://www.scielo.br/pdf/se/v32n3/0102-6992-se-32-03-725.pdf. Acesso em: 21 maio 2019.

61 MISKLOCI, Richard; CAMPANA, Maximiliano. “Ideologia de gênero": notas para a genealogia de um pânico moral contemporâneo. Revista Sociedade e Estado, v. 32, n. 3, p. 725-747, set./dez. 2017. p. 742-743. Disponível em: http://www.scielo.br/pdf/se/v32n3/0102-6992-se-32-03-725.pdf. Acesso em: 21 maio 2019.

${ }^{62}$ BRASIL. [Constituição (1988)]. Constituição da República Federativa do Brasil de 1988. Brasília, DF: Presidência da República, [2016]. Disponível em:

http://www.planalto.gov.br/ccivil_03/constituicao/constituicao.htm. Acesso em: 1 jan 2017.

${ }^{63}$ CARDIN, Valéria Silva Galdino; SEGATTO, Antonio Carlos; CAZELATTO, Caio Eduardo Costa. O exercício ilegítimo do discurso de ódio homofóbico sob a ótica da sexualidade e da dignidade humana. Revista Jurídica - UNICURITIBA, Curitiba, v. 1, n. 46, p. 90-118, 2017. p. 107. Disponível em: http://revista.unicuritiba.edu.br/index.php/RevJur/article/view/2001. Acesso em: 22 maio 2019.

${ }^{64}$ CAZELATTO, Caio Eduardo Costa; CARDIN, Valéria Silva Galdino. 0 discurso de ódio e minorias sexuais. Rio de Janeiro: Lumen Juris, 2018. 
ISSN 1981-3694

(DOI): $10.5902 / 1981369438872$

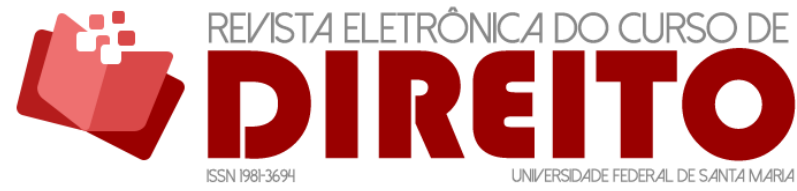

DAS CONSEQUÊNCIAS DA DEMONIZAÇÃO DA PLURALIDADE NAS ESCOLAS À LUZ DO ESTATUTO DA DIVERSIDADE SEXUAL E DE

GÊNERO

VALERIA SILVA GALDINO CARDIN RAISSA ARANTES TOBBIN

diversidade sexual. Logo, também verifica-se que, por mais que tenha por interesse superficial a proteção da família, dos costumes e das crianças e dos adolescentes, tal frente também tem sua ideologia, que é baseada em modelos e padrões que não coadunam com a evolução social e cultural de uma comunidade ou nação, fato que não ocorreria se esses ditames não constrangessem e segregassem muitos indivíduos em sociedade.

Muito mais do que agitação e discussão política, a frente reacionária à “ideologia de gênero" também incita a demonização da educação de gênero nas escolas, visto que a concebe como sendo temática reservada ao império da entidade familiar e acaba por obstar a concretização de uma sociedade mais justa, livre e igualitária, já que impede a livre expressão da sexualidade e do gênero.

\section{AS CONSEQUÊNCIAS DA DEMONIZAÇÃO DA EDUCAÇÃO DE GÊNERO}

Diversos são os fatores negativos advindos da demonização da educação de gênero nas escolas. A primeira, e a mais deprimente, é a da possibilidade de manutenção ou de aumento dos índices de violência em razão da diversidade sexual e de gênero, ou seja, exposição ainda maior ao preconceito e à discriminação de um grupo socialmente vulnerável. Segundo a pesquisa Violência LGBT+ no período eleitoral e pós-eleitoral, realizada em 2019 pela organização de mídia Gênero e Número e financiada pela Fundação Ford, "existe uma escalada de violência contra a população LGBT no Brasil após o período eleitoral” de 2018. Essa é a percepção “de 92,5\% de lésbicas, gays, bissexuais e transexuais entrevistados". Além disso, mais da metade dos entrevistados, precisamente 51\%, afirmou ter sofrido algum tipo de violência em razão da orientação sexual e identidade de gênero desde as eleições de $2018^{65}$.

Os autores Reis e Eggert compreendem que, à guisa de uma moral “cristã”, "as mulheres feministas e as pessoas LGBT se transformaram, na visão de quem prega contra a 'ideologia de gênero', em uma força do mal, no inimigo, a ser combatido a qualquer custo". ${ }^{66}$ Para Vieira e Sampaio, a não aceitação da diversidade também pode ocasionar "o acúmulo involuntário pelos

\footnotetext{
${ }^{65}$ MENA, Fernanda. Mais da metade dos LGBT diz ter sofrido violência desde as eleições. Folha de São Paulo, 20 mar. 2019. Disponível em: https://www1.folha.uol.com.br/cotidiano/2019/03/mais-da-metadedos-lgbt-diz-ter-sofrido-violencia-desde-as-eleicoes.shtml. Acesso em: 16 jun 2019.

${ }_{66}$ REIS, Toni; EGGERT, Edla. Ideologia de Gênero: uma falácia construída sobre os planos de educação brasileiros. Educação e Sociedade, Campinas, v. 38, n. 138, p. 9-26, jan./mar. 2017. p. 19. Disponível em: http://www.scielo.br/pdf/es/v38n138/1678-4626-es-38-138-00009.pdf. Acesso em: 21 maio 2019.
} 
ISSN 1981-3694

(DOI): $10.5902 / 1981369438872$

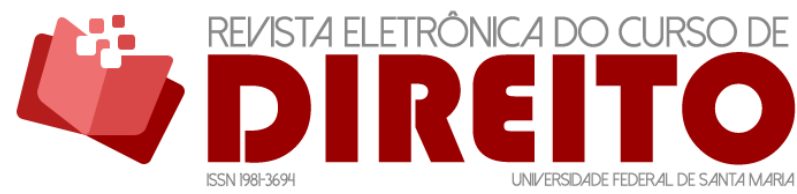

DAS CONSEQUÊNCIAS DA DEMONIZAÇÃO DA PLURALIDADE NAS ESCOLAS À LUZ DO ESTATUTO DA DIVERSIDADE SEXUAL E DE

GÊNERO

VALERIA SILVA GALDINO CARDIN RAISSA ARANTES TOBBIN

alunos de "sentimentos indesejados, frustrações, preocupações e tantas outras situações ao longo da vida que influenciam diretamente no aparecimento dos transtornos de ansiedade"67.

Como entendem Marcon, Prudêncio e Gesser, "a manutenção de binarismos e fundamentalismos nas práticas pedagógicas 'oprime as sexualidades divergentes no modelo heteronormativo' e 'limita a garantia dos direitos sexuais e reprodutivos"”68. Em pesquisas realizadas no âmbito do Ensino Médio brasileiro, Rosistolato verificou que poucos são os meninos que procuram ou se sentem confortáveis em falar sobre sexo em sala de aula, ao contrário das meninas, que realizam questionamentos e frequentam os atendimentos especializados; que as equipes que envolvem o trabalho com a sexualidade raramente são compostas por homens; e que as meninas vão com frequência ao ginecologista, mas que os meninos raramente vão ao médico durante a puberdade ${ }^{69}$. Como demonstram Pereira e Santos, apesar da população feminina ter mais acesso à educação nos três níveis de ensino, os estereótipos de gênero ainda fazem com que estas ganhem menos que os homens no mundo do trabalho ${ }^{70}$.

Outra faceta da demonização da educação de gênero, como já citado, é a omissão legislativa no que tange à regulamentação da temática. Ainda pior do que a omissão é a produção legislativa que visa coibir ou afastar a diversidade do ensino regular. Em 2018, o Ministro Dias Toffoli, do Supremo Tribunal Federal, em decisão proferida na Arguição de Descumprimento de Preceito Fundamental (ADPF) 526, deferiu liminar para suspender dispositivo da Lei Orgânica do Município de Foz do Iguaçu (PR), que proibia, na rede de ensino, a veiculação de conteúdo relacionado à ideologia de gênero e à orientação sexual ${ }^{71}$.

67 VIEIRA, Tereza Rodrigues; SAMPAIO, Liliana Lopes Pedral. Personalidade, identidade civil e autorreconhecimento: consequências psicológicas causadas por um prenome indesejado. In: MIRANDA, José Eduardo; CARDIN, Valéria Silva Galdino. (orgs.). Direitos da personalidade: reconhecimento, garantias e perspectivas. Curitiba: Juruá, 2018. p. 105-120. p. 208.

${ }_{68}$ MARCON, Amanda Nogara; PRUDÊNCIO, Luísa Evangelista Vieira; GESSER, Marivete. Políticas públicas relacionadas à diversidade sexual na escola. Revista Psicologia Escolar e Educacional, São Paulo, v. 20, n. 2, p. 291-301, maio/ago. 2016. p. 292. Disponível em: http://www.scielo.br/pdf/pee/v20n2/21753539-pee-20-02-00291.pdf. Acesso em: 29 maio 2019.

69 ROSISTOLATO, Rodrigo Pereira da Rocha. Gênero e cotidiano escolar: Gênero e cotidiano escolar: dilemas e perspectivas da dilemas e perspectivas da intervenção escolar na socialização afetivo socialização afetivo-sexual dos -sexual dos adolescentes. Revista Estudos Feministas, Florianópolis, v. 17, n. 1, p. 11-30, jan./abr. 2009. Disponível em: http://www.scielo.br/pdf/ref/v17n1/a02v17n1.pdf. Acesso em: 29 maio 2019.

70 PEREIRA, Maycon Samuel Xavier; SANTOS, Marcelo Loeblein dos. Igualdade de gênero nas relações de trabalho: superando os estereótipos entre homem e mulher. Revista Eletrônica do Curso de Direito da UFMS, Santa Maria, v. 5, n. 2, 2010. p. 13. Disponível em:

https://periodicos.ufsm.br/revistadireito/article/view/7051/4264. Acesso em: 20 maio 2019.

71 MINISTRO suspende lei de Foz do Iguaçu (PR) que proíbe abordagem sobre gênero nas escolas municipais. Notícias STF, 5 jul. 2018. Disponível em:

http://www.stf.jus.br/portal/cms/verNoticiaDetalhe. asp?idConteudo=383353. Acesso em: 28 maio 2019. 
ISSN 1981-3694

(DOI): $10.5902 / 1981369438872$

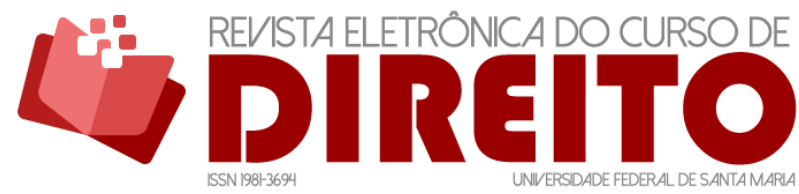

DAS CONSEQUÊNCIAS DA DEMONIZAÇÃO DA PLURALIDADE NAS ESCOLAS À LUZ DO ESTATUTO DA DIVERSIDADE SEXUAL E DE

GÊNERO

VALERIA SILVA GALDINO CARDIN RAISSA ARANTES TOBBIN

Também em 2018, o Ministro Luís Roberto Barroso, do Supremo Tribunal Federal (STF) concedeu liminar para suspender parte de dispositivo de lei do Município de Palmas (TO) que proíbe o ensino sobre gênero e sexualidade na rede pública municipal. Tal decisão foi tomada na Arguição de Descumprimento de Preceito Fundamental (ADPF) 465, ajuizada pela ProcuradoriaGeral de República (PGR) contra parte do artigo $1^{\circ}$ da Lei Municipal $n^{\circ} 2.243 / 2016$, acerca do plano municipal de educação. 0 trecho impugnado previa a vedação da discussão e a utilização de "material didático e paradidático sobre a ideologia ou teoria de gênero, inclusive promoção de condutas, permissão de atos e comportamentos que induzam à referida temática, bem como os assuntos ligados à sexualidade e à erotização"72. Nos termos do entendimento do Ministro Barroso, tal norma "suprime o campo do saber da sala de aula e do horizonte informacional de crianças e jovens", uma vez que interfere em diretrizes constitucionais que orientam as ações em matéria de educação ${ }^{73}$.

Em 2019, o mesmo aconteceu perante o Tribunal de Justiça de Sergipe (TJSE), que declarou inconstitucional a Lei Municipal $n^{\circ} 625$ que proibia a inclusão, na grade curricular das escolas públicas mantidas pela Prefeitura de Itaporanga D’Ajuda, de atividades que reproduziam conceitos de ideologia de gênero ${ }^{74}$. Apesar de este não ser o objeto de estudo do presente trabalho, ressalta-se que a demonização da educação de gênero também é fortemente associada ao movimento Escola sem Partido, que ganhou força nos últimos anos e que foi amplamente discutido ao longo das eleições brasileiras de 2018. Como compreendem Batista, Costa e Freitas, tal protejo de educação pretende coibir dois tipos de condutas: "a doutrinação política e ideológica e a realização de atividades em conflito com as convicções religiosas ou morais dos pais" dos alunos, visto que "a educação deveria limitar-se à mera instrução, ou seja, à simples transmissão de conhecimentos necessários para a formação profissional"75.

\footnotetext{
72 SUSPENSA norma que proibia abordagem de questões de gênero nas escolas de Palmas (TO). Notícias STF, 27 ago 2018. Disponível em: http://stf.jus.br/portal/cms/verNoticiaDetalhe.asp?idConteudo=388055. Acesso em: 22 maio 2019.

73 SUSPENSA norma que proibia abordagem de questões de gênero nas escolas de Palmas (TO). Notícias STF, 27 ago 2018. Disponível em: http://stf.jus.br/portal/cms/verNoticiaDetalhe.asp?idConteudo=388055. Acesso em: 22 maio 2019.

${ }^{74}$ SANTANA, Cassia. TJ libera debate sobre ideologia de gênero nas escolas de Itaporanga. InfoNet, 19 jun. 2019. Disponível em: https://infonet.com.br/noticias/educacao/tj-libera-debate-sobre-ideologia-degenero-nas-escolas-de-itaporanga/. Acesso em: 20 jun 2019.

75 BATISTA, Cristiano; COSTA, Fabrício Veiga; FREITAS, Sérgio Henriques Zandona. 0 equívoco do movimento "escola sem partido" num contexto constitucional de educação democrática, inclusiva e emancipatória. In: COSTA, Fabrício Veiga; MOTTA, Ivan Dias da; FREITAS, Sérgio Henrique Zandona. (orgs.). Proposições crítico-reflexivas sobre o direito à educação na sociedade contemporânea. Coleção Caminhos Metodológicos do Direito. Maringá: IDDM, 2017. p. 198-225. p. 205.
} 
ISSN 1981-3694

(DOI): $10.5902 / 1981369438872$

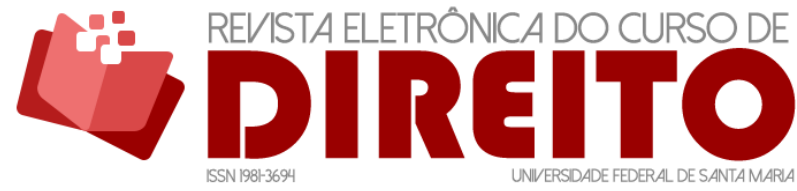

DAS CONSEQUÊNCIAS DA DEMONIZAÇÃO DA PLURALIDADE NAS ESCOLAS À LUZ DO ESTATUTO DA DIVERSIDADE SEXUAL E DE

GÊNERO

VALERIA SILVA GALDINO CARDIN RAISSA ARANTES TOBBIN

Além disso, a formação ética e religiosa "seria função exclusiva da família e, ademais, a escola não poderia ensinar teorias que colocassem em dúvida ou chocassem com as crenças religiosas de seus familiares". Entretanto, para os autores, essa concepção de educação "é totalmente equivocada", uma vez que "o simples ensino de competências (o saber fazer), que se limite a incluir as pessoas, como autônomas, em uma cadeia produtiva, possibilita a concretização de uma sociedade cada vez mais desigual". Seria a consagração da educação como "uma forma de instrução precária que serve ao mercado de trabalho, mas não proporciona autonomia do sujeito"76. Ainda, para os autores, a educação deve ser um processo de formação integral do ser humano, de forma que possibilite que este se transforme em um indivíduo capaz de reflexões críticas e de autodeterminar-se, sempre com autonomia e responsabilidade. Nesse sentido, é passível de verificação porque Paulo Freire, o patrono da educação brasileira, tem sido tão atacado por esse movimento. A educação, para o pensador, é direcionada para a emancipação do ser e privilegia a autonomia do sujeito racional que, "sem negar os saberes construídos na experiência, é capaz de romper com a estrutura social opressora"77.

Como entendem Longaray e Ribeiro, a escola não é uma instância de aprendizagem que apenas transmite/produz conhecimento, mas que, "a partir de múltiplos discursos, práticas, códigos, regras, saberes, determina o que os sujeitos podem ou não fazer, posicionando-os na sociedade"78. Como o próprio Paulo Freire preceitua, "ninguém educa ninguém, ninguém educa a si mesmo, os homens se educam entre si, mediatizados pelo mundo"79.

É a partir das primeiras relações de alteridade que o sujeito vive e passa a se relacionar e é por meio da convivência e da troca que este pode se expressar e fortalecer suas conexões

76 BATISTA, Cristiano; COSTA, Fabrício Veiga; FREITAS, Sérgio Henriques Zandona. O equívoco do movimento "escola sem partido" num contexto constitucional de educação democrática, inclusiva e emancipatória. In: COSTA, Fabrício Veiga; MOTTA, Ivan Dias da; FREITAS, Sérgio Henrique Zandona. (orgs.). Proposições crítico-reflexivas sobre o direito à educação na sociedade contemporânea. Coleção Caminhos Metodológicos do Direito. Maringá: IDDM, 2017. p. 198-225. p. 215.

77 BATISTA, Cristiano; COSTA, Fabrício Veiga; FREITAS, Sérgio Henriques Zandona. 0 equívoco do movimento "escola sem partido" num contexto constitucional de educação democrática, inclusiva e emancipatória. In: COSTA, Fabrício Veiga; MOTTA, Ivan Dias da; FREITAS, Sérgio Henrique Zandona. (orgs.). Proposições crítico-reflexivas sobre o direito à educação na sociedade contemporânea. Coleção Caminhos Metodológicos do Direito. Maringá: IDDM, 2017. p. 198-225. p. 212.

78 LONGARAY, Deise Azevedo; RIBEIRO, Paula Regina Costa. A homossexualidade e a homofobia no espaço escolar: analisando algumas estratégias de controle. In: MAIO, Eliane Rose; CORREA, Crishna Mirella de Andrade. (orgs). Gênero, direito e diversidade sexual: trajetórias escolares. Maringá: Uduem, 2013. p. 183.

79 FREIRE, 1987, p. 68 apud SILVA, Ana Maria Zanoni. Por uma educação dialógica. In: FINOTTI, Laura Fontes Tomaz; TOMAZ, Loyana Chirstian de Lima; TOMAZ, Rozaine Aparecida Fontes. (orgs.). Educação e interdisciplinaridade: diálogos com a psicologia, a filosofia e o direito. Uberlândia: Composer, 2015. p. 241-256. p. 242. 
ISSN 1981-3694

(DOI): $10.5902 / 1981369438872$

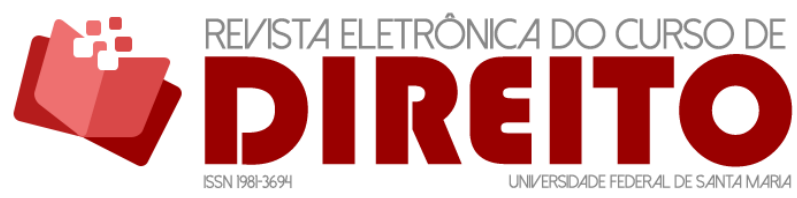

DAS CONSEQUÊNCIAS DA DEMONIZAÇÃO DA PLURALIDADE NAS ESCOLAS À LUZ DO ESTATUTO DA DIVERSIDADE SEXUAL E DE

GÊNERO

VALERIA SILVA GALDINO CARDIN RAISSA ARANTES TOBBIN

afetivas, obtendo a confiança necessária para se inserir socialmente ${ }^{80}$. 0 que se destaca desse tópico é a falta de informação e contextualização acerca das concepções de educação de gênero e de diversidade sexual. Tal problemática fomenta o discurso de ódio que combate a denominada “ideologia de gênero".

Mas por que tratar da educação de gênero nas escolas? Por que esta deve ser um espaço acolhedor da diversidade? Qual é a sua real importância e impacto? Para Piovesan e Silva, por vezes, é insuficiente tratar o indivíduo de forma genérica e abstrata, fazendo-se necessária sua especificação. "Nesta ótica, determinados sujeitos de direitos, ou determinadas violações de direitos, exigem uma resposta específica e diferenciada", uma vez que, ao lado do direito à igualdade, surge o direito fundamental à diferença, que necessita de tratamento especial ${ }^{81}$.

Logo, a educação de gênero não pretende ser uma ideologia ou desvirtuar e acabar com os padrões sociais já estabelecidos. No entanto, esta tem por escopo a reflexão crítica acerca desses modelos e visa orientar e romper com o preconceito e com a marginalização. Idealiza a igualdade entre o masculino e o feminino e a aceitação e o reconhecimento da diversidade sexual e de gênero por meio da outorga de direitos e de empoderamento de indivíduos constantemente esquecidos ou oprimidos. Além disso, cumpre ressaltar que é certo que a aceitação da diversidade é reconhecida por ser uma causa historicamente contextualizada à esquerda do cenário político e que esse setor também já utilizou no passado a aceitação da diversidade como discurso de manobra. Logo, esse trabalho não ressalta marcadores ou tem por intuito sacramentar documentos criados em períodos ou por governos "mais propensos" à aceitação da diversidade.

Também leva em consideração a pluralidade de concepções políticas e o respeito à liberdade de expressão, de crença e de convicções filosóficas e religiosas. Contudo, não deixa de questionar e apontar que o combate à chamada “ideologia de gênero" é ação maléfica à evolução social, uma vez que ocasiona a marginalização de uma parcela considerável da sociedade. Logo, seu compromisso é com a proteção do indivíduo, vulnerável ao preconceito que tem por fundamento noções que deveriam orientar o campo individual do discurso, nunca o

\footnotetext{
${ }^{80}$ NÚÑEZ, Olivia Guadalupe Penilla. Encuentros (afectivos) para la reconfiguración social. In: ROSAS, Rocío Enríquez; SÁNCHEZ, Oliva Lópes. (orgs.). Masculinidades, familias y comunidades afectivas. Guadalajara: ITESO/ UNAM, 2018. p. 165-180.

81 PIOVESAN, Flávia; SILVA, Roberto B. Dias da. Igualdade e diferença: o direito à livre orientação sexual na Corte Europeia de Direito Humanos e no Judiciário brasileiro. In: BUGLIONE, Samantha; VENTURA, Miriam. (orgs.). Direito à reprodução e à sexualidade: uma questão de ética e justiça. Rio de Janeiro: Lumen Juris, 2010. p. 65-105. p. 67.
} 
ISSN 1981-3694

(DOI): $10.5902 / 1981369438872$

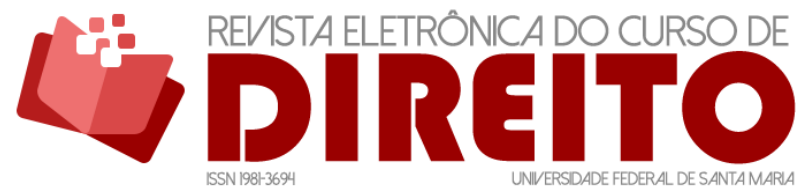

DAS CONSEQUÊNCIAS DA DEMONIZAÇÃO DA PLURALIDADE NAS ESCOLAS À LUZ DO ESTATUTO DA DIVERSIDADE SEXUAL E DE

GÊNERO

VALERIA SILVA GALDINO CARDIN RAISSA ARANTES TOBBIN

público. Assim, essa pesquisa compreende que a educação não pode ser um casulo que objetive proteger os seus alunos dos enfrentamentos sociais e da compreensão da desigualdade.

Melhor dizendo, o ensino imaculado peca porque não prepara o seu aluno para a dificuldade e não the proporciona condições necessárias para suportar as adversidades da vida humana. Nesse sentido, é manifesto o papel da escola de ser um ambiente que não compactua com esse panorama de segregação de direitos e de imposição de modos e de padrões de vida.

\section{O DIREITO À EDUCAÇÃO À LUZ DO ESTATUTO DA DIVERSIDADE SEXUAL E DE GÊNERO}

Tendo por escopo garantir direitos e combater desigualdades de gênero e a marginalização da comunidade LGBTQI+, a Ordem dos Advogados do Brasil (OAB) apresentou, em 2011, à Comissão de Direitos Humanos e Participação Legislativa do Senado Federal o anteprojeto do Estatuto da Diversidade Sexual e de Gênero. Em audiência pública, realizada em 22 de março de 2011, o Conselho Federal aprovou, por meio da criação da Portaria 16/2011, a constituição da Comissão Especial da Diversidade Sexual e de Gênero, que firmou o compromisso de qualificar os advogados e de elaborar um estatuto que contemplasse os principais direitos relativos à sexualidade e à identidade de gênero.

A Comissão foi presidida por Maria Berenice Dias (RS) e integrada por Adriana Galvão Moura Abílio (SP); Jorge Marcos Freitas (DF); Marcos Vinicius Torres Pereira (RJ) e Paulo Tavares Mariante (SP). Participaram como consultores: Daniel Sarmento (RJ); Luis Roberto Barroso (RJ); Rodrigo da Cunha Pereira (MG) e Tereza Rodrigues Vieira (SP). A elaboração do Estatuto também contou com a participação das Comissões da Diversidade Sexual e de Gênero das Seccionais e Subseções da OAB. A coleta de assinaturas para a apresentação do projeto por iniciativa popular chegou a 100 mil adesões, fato que evidenciou o apoio popular ${ }^{82}$.

Em abril de 2020, verificou-se que o Projeto de Lei que visa a aprovação do Estatuto continua em tramitação perante o Senado Federal, encontrando-se junto da Comissão de Transparência, Governança, Fiscalização e Controle e Defesa do Consumidor desde 15 de março

82 ORDEM DOS ADVOGADOS DO BRASIL (OAB). Conselho Federal. Comissão Especial da Diversidade Sexual e de Gênero. Anteprojeto de Lei. Estatuto da Diversidade Sexual e de Gênero. 2017. Disponível em: https://legis.senado.leg.br/sdleg-getter/documento?dm=7302364\&disposition=inline. Acesso em: 20 maio 2019. 
ISSN 1981-3694

(DOI): $10.5902 / 1981369438872$

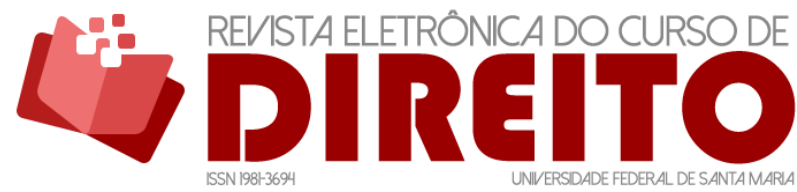

DAS CONSEQUÊNCIAS DA DEMONIZAÇÃO DA PLURALIDADE NAS ESCOLAS À LUZ DO ESTATUTO DA DIVERSIDADE SEXUAL E DE

GÊNERO

VALERIA SILVA GALDINO CARDIN RAISSA ARANTES TOBBIN

de 2019, tendo por Relator o Senador Paulo Rocha (PT) ${ }^{83}$. Quanto ao conteúdo e a proposta do Estatuto, nos termos do disposto em sua Apresentação, é chegada "a hora de acabar com a invisibilidade jurídica deste segmento da população, que é alvo de perversa discriminação em razão da orientação sexual e identidade de gênero"84.

Assim, impõe-se verdadeira mudança de paradigma a toda a sociedade, uma vez que “todos precisam aprender a viver com a diferença. Não só no mundo público, mas nos mais diversos segmentos da iniciativa privada". Ainda, para os idealizadores do Projeto, "a inexistência de lei não significa ausência de direito e nem pode deixar ninguém à margem da tutela estatal. A democracia é o direito de todos, não só da maioria”. E, para o documento, "as minorias alvo do preconceito e da discriminação merecem tutela diferenciada e mais atenta para terem seus direitos reconhecidos" ${ }^{\prime 85}$.

O resultado da omissão estatal, de acordo com o Estatuto, é a condenação de indivíduos à invisibilidade, que se tornam reféns de práticas homofóbicas que os colocam em situação de absoluta vulnerabilidade social ${ }^{86}$. Conforme compreende Dias, o Estatuto da Diversidade Sexual, elaborado pela Ordem dos Advogados do Brasil (OAB), é o mais "arrojado anteprojeto deste século, quer pela sua abrangência, quer pelo seu alcance, já que se compromete com a democracia e com a luta pelo direito dos cidadãos brasileiros”. Nesse sentido, o Conselho Federal da OAB também desempenhou papel fundamental, tendo em vista que "assumiu a missão quase impossível de elaborar um projeto legislativo e promover uma ampla revisão da legislação infraconstitucional para assegurar os direitos que já vinham sendo reconhecidos", tanto no âmbito jurisprudencial como na esfera administrativa. ${ }^{87}$

\footnotetext{
${ }^{83}$ BRASIL. Senado Federal. Projeto de Lei do Senado $n^{\circ} 134$, de 2018. Institui o Estatuto da Diversidade Sexual e de Gênero. Disponível em: https://www25.senado.leg.br/web/atividade/materias//materia/132701. Acesso em: 20 maio 2019.

84 ORDEM DOS ADVOGADOS DO BRASIL (OAB). Conselho Federal. Comissão Especial da Diversidade Sexual e de Gênero. Anteprojeto de Lei. Estatuto da Diversidade Sexual e de Gênero. 2017. Disponível em: https://legis.senado.leg.br/sdleg-getter/documento?dm=7302364\&disposition=inline. Acesso em: 20 maio 2019.

85 ORDEM DOS ADVOGADOS DO BRASIL (OAB). Conselho Federal. Comissão Especial da Diversidade Sexual e de Gênero. Anteprojeto de Lei. Estatuto da Diversidade Sexual e de Gênero. 2017. Disponível em: https://legis.senado.leg.br/sdleg-getter/documento?dm=7302364\&disposition=inline. Acesso em: 20 maio 2019.

86 ORDEM DOS ADVOGADOS DO BRASIL (OAB). Conselho Federal. Comissão Especial da Diversidade Sexual e de Gênero. Anteprojeto de Lei. Estatuto da Diversidade Sexual e de Gênero. 2017. Disponível em: https: / /legis.senado.leg.br/sdleg-getter/documento?dm=7302364\&disposition=inline. Acesso em: 20 maio 2019.

87 DIAS, Maria Berenice. Um estatuto para a diversidade sexual. In: PEREIRA, Rodrigo da Cunha. Família: entre o público e o privado (coord.). Porto Alegre: Magister/IBDFAM, 2012. p. 176-192. p. 177.
} 
ISSN 1981-3694

(DOI): $10.5902 / 1981369438872$

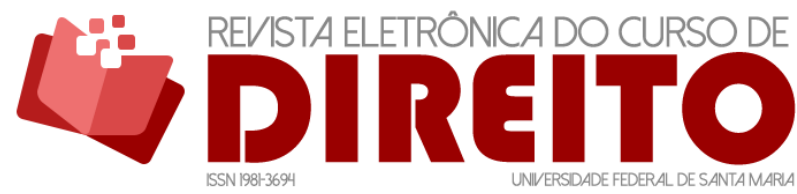

DAS CONSEQUÊNCIAS DA DEMONIZAÇÃO DA PLURALIDADE NAS ESCOLAS À LUZ DO ESTATUTO DA DIVERSIDADE SEXUAL E DE

GÊNERO

VALERIA SILVA GALDINO CARDIN RAISSA ARANTES TOBBIN

O Estatuto dedica um capítulo exclusivo ao Direito à Educação, de forma que menciona, em seu artigo 56, que os estabelecimentos públicos e privados de ensino têm o dever de "promover a liberdade, a tolerância, a igualdade, a diversidade e o respeito entre as pessoas", independentemente de sua orientação sexual ou identidade de gênero. Assim, os professores, diretores, supervisores, psicólogos, psicopedagogos e todos os que trabalham em estabelecimentos de ensino públicos e privados têm o dever de "evitar qualquer atitude preconceituosa ou discriminatória por orientação sexual e identidade de gênero" (artigo 57). Além disso, os profissionais da educação, nos termos do artigo 58 do Estatuto em comento, devem abordar os temas relacionados à sexualidade, "adotando materiais didáticos que não reforcem a discriminação com base na orientação sexual ou identidade de gênero" ${ }^{88}$.

Conforme o artigo 59 do Estatuto, gera responsabilidade civil e penal a omissão dos dirigentes e dos professores que não coibirem, no ambiente escolar, condutas que visem “intimidar, ameaçar, ofender, castigar, submeter, ridicularizar, difamar, injuriar, caluniar ou expor aluno a constrangimento físico ou moral, em decorrência de sua orientação sexual ou identidade de gênero". 0 documento também prevê, em seu artigo 60, que a programação e as atividades escolares referentes a datas comemorativas devem "atentar à multiplicidade de formações familiares, de modo a evitar qualquer constrangimento dos alunos filhos de famílias homoafetivas" ${ }^{89}$, não privilegiando, assim, apenas um modelo de família.

O Projeto também pontua que a capacitação do profissional da educação também é essencial para a possibilidade de uma educação inclusiva, devendo o Poder Público promover ações que tenham por objetivo "elevar a escolaridade de lésbicas, gays, bissexuais, transgêneros e intersexuais, de modo a evitar a evasão escolar" (artigo 61). Outro ponto mencionado pelo documento é o da garantia de utilização do nome social para transgêneros e intersexuais em todos os estabelecimentos de ensino fundamental e médio, como também nos cursos superiores, desde o ato da matrícula e a qualquer tempo, devendo o nome social "constar em todos os assentos escolares e registros acadêmicos". (artigo 62 do Estatuto) $)^{90}$.

88 ORDEM DOS ADVOGADOS DO BRASIL (OAB). Conselho Federal. Comissão Especial da Diversidade Sexual e de Gênero. Anteprojeto de Lei. Estatuto da Diversidade Sexual e de Gênero. 2017. Disponível em: https://legis.senado.leg.br/sdleg-getter/documento?dm=7302364\&disposition=inline. Acesso em: 20 maio 2019.

89 ORDEM DOS ADVOGADOS DO BRASIL (OAB). Conselho Federal. Comissão Especial da Diversidade Sexual e de Gênero. Anteprojeto de Lei. Estatuto da Diversidade Sexual e de Gênero. 2017. Disponível em: https: / / legis.senado.leg.br/sdleg-getter/documento?dm=7302364\&disposition=inline. Acesso em: 20 maio 2019.

90 ORDEM DOS ADVOGADOS DO BRASIL (OAB). Conselho Federal. Comissão Especial da Diversidade Sexual e de Gênero. Anteprojeto de Lei. Estatuto da Diversidade Sexual e de Gênero. 2017. Disponível em: 
ISSN 1981-3694

(DOI): $10.5902 / 1981369438872$

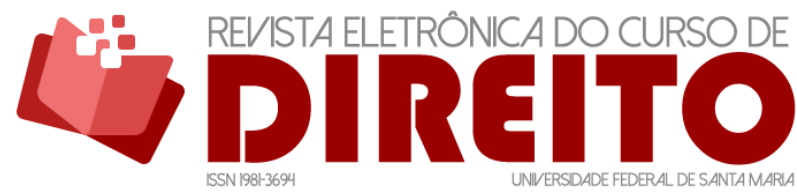

DAS CONSEQUÊNCIAS DA DEMONIZAÇÃO DA PLURALIDADE NAS ESCOLAS À LUZ DO ESTATUTO DA DIVERSIDADE SEXUAL E DE

GÊNERO

VALERIA SILVA GALDINO CARDIN RAISSA ARANTES TOBBIN

Como descreve Vieira, o Estatuto da Diversidade Sexual vislumbra a efetivação, no Brasil, "da promoção da cidadania e do combate ao preconceito, à vulnerabilidade e à discriminação por orientação sexual e por identidade de gênero". Ainda, o anteprojeto reconhece igual dignidade jurídica a heterossexuais, homossexuais, bissexuais, transexuais, travestis, transgêneros, intersexuais, individualmente, em comunhão e nas relações sociais, sendo respeitadas as distintas formas de orientação sexual e de gênero ${ }^{91}$. Nesse ponto, a demonização da educação de gênero e das questões relacionadas à sexualidade atrapalham a tramitação do mencionado Estatuto perante o Congresso Nacional. A pressão dos setores mais conservadores da sociedade e a oposição das bancadas que os representam fazem com que projetos que contemplem o respeito à diversidade sejam deixados de lado, esquecidos e engavetados, fato que representa e acentua a omissão legislativa quanto ao tema.

No entender de Dias, na sociedade contemporânea, "nada justifica a omissão do sistema jurídico frente à população formada por lésbicas, gays, bissexuais, travestis, transexuais, transgêneros e intersexuais". Assim, é urgente a necessidade de aprovação de legislação que assegure a essa significativa parcela de cidadãos "o direito à vida; à integridade física e psíquica e à inclusão social" ${ }^{92}$. Nesse contexto, para Longaray e Ribeiro, a discussão acerca das temáticas de gênero e de sexualidade são estratégias que contribuem para a minimização de estigmas, já que "a escola, ao afirmar a heterossexualidade como a identidade sexual natural, acaba permitindo e fortalecendo a homofobia em seu âmbito escolar", sendo o seu papel promover a cultura do respeito ${ }^{93}$.

Mas como a escola deve então trabalhar as questões de gênero? Em que momento propor tais debates? Será que os seus profissionais estão realmente aptos para tanto? Inicialmente, mesmo que a escola ainda não esteja totalmente preparada para tratar desse debate ou não queira, a realidade social se impõe de forma que não pode mais ser ignorada. Reconhecem Carvalho e Rabay que a construção atual do termo 'gênero', do que é gênero e das questões pertinentes à temática não é de fácil conceituação ou apreensão. As autoras apontam

https://legis.senado.leg.br/sdleg-getter/documento?dm=7302364\&disposition=inline. Acesso em: 20 maio 2019.

91 VIEIRA, Tereza Rodrigues. Direito à diversidade de gênero, redesignações identitárias e o Estatuto da Diversidade Sexual. In: PEREIRA, Rodrigo da Cunha. Família: entre o público e o privado (coord.). Porto Alegre: Magister/IBDFAM, 2012. p. 359-369. p. 365.

92 DIAS, Maria Berenice. Estatuto da Diversidade Sexual: uma lei por iniciativa popular. Disponível em: http:// www.mariaberenice.com.br. Acesso em: 21 maio 2019.

${ }_{93}$ LONGARAY, Deise Azevedo; RIBEIRO, Paula Regina Costa. A homossexualidade e a homofobia no espaço escolar: analisando algumas estratégias de controle. In: MAIO, Eliane Rose; CORREA, Crishna Mirella de Andrade. (orgs). Gênero, direito e diversidade sexual: trajetórias escolares. Maringá: Uduem, 2013. p. 187. 
ISSN 1981-3694

(DOI): $10.5902 / 1981369438872$

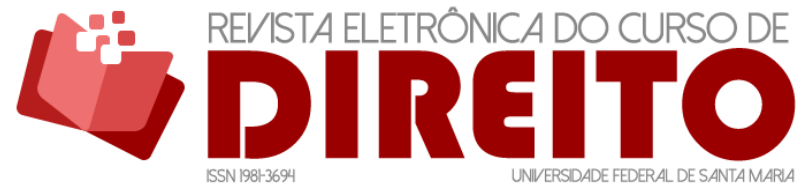

DAS CONSEQUÊNCIAS DA DEMONIZAÇÃO DA PLURALIDADE NAS ESCOLAS À LUZ DO ESTATUTO DA DIVERSIDADE SEXUAL E DE

GÊNERO

VALERIA SILVA GALDINO CARDIN RAISSA ARANTES TOBBIN

também que tal problemática também encontra espaço no ambiente escolar, uma vez que muitos educadores ainda desconhecem as principais teorias, conceituações ou não visualizam como problema os ditames tradicionais do que é gênero ${ }^{94}$. Assim, de início, a escola deve, no mínimo, reconhecer a diversidade e ser um ambiente acolhedor. Ainda, é a partir da proposição de reflexões críticas que, na prática, esta ensinará seus alunos a lidar com o assunto e se aprimorará diante do combate ao preconceito e à discriminação.

Como visualiza Machado, é possível a utilização de filmes, criação de textos de discussão, resenhas, blogs, a criação de debates, júris simulados, entre outros. 0 professor também precisa combater práticas discriminatórias que apontem para estereótipos, a exemplo do que é ser menina e do que é ser menino95. Como preceituam os Parâmetros Curriculares Nacionais, criar espaços para a reflexão e o debate dessas questões sem personalizá-las é o que pode ajudar os jovens "a passar por essa fase com menos angústias e turbulências, e sem precisar armar uma couraça protetora/repressora ou transformar a sexualidade em expressão de rebeldia" ${ }^{96}$. Portanto, é evidente que as questões que envolvem a sexualidade e o gênero são complexas. Entretanto, a sua reflexão possibilita a superação de limites marcados por palavras de ordem que não têm mais espaço ante a evolução cultural e social.

Dessa forma, a escola deve informar e problematizar o debate de tabus sociais, buscando sempre a condução desses assuntos sob a perspectiva de um viés democrático. Além disso, por óbvio que a postura escolar nunca conseguirá ser totalmente isenta, mas esta deve ser aberta, acolhedora e intervir diante de casos em que haja ofensa aos direitos humanos e aos direitos fundamentais de seus alunos, principalmente dos mais vulneráveis.

\section{CONCLUSÃO}

O desenvolvimento da sexualidade inicia-se desde a mais tenra idade; logo, nem mesmo as crianças estão imunes às dúvidas, aos anseios e aos questionamentos acerca da aceitação do

${ }^{94}$ CARVALHO, Maria Eulina Pessoa de; RABAY, Glória. Usos e incompreensões do conceito de gênero no discurso educacional no Brasil. Revista Estudos Feministas, Florianópolis, v. 23, n. 1, p. 119-136, jan./abr. 2015. Disponível em: https://periodicos.ufsc.br/index.php/ref/article/view/37466/28761. Acesso em: 21 maio 2019.

${ }_{95}$ MACHADO, Carla Silva. Gênero, sexualidade e a importância de práticas pedagógicas interculturais. Revista Reflexão e Ação, Santa Cruz do Sul, v. 24, n. 1, p. 177-191, jan./abr. 2016. Disponível em: https://online.unisc.br/seer/index.php/reflex/article/view/6992/pdf. Acesso em: 25 maio 2019.

96 BRASIL. Secretaria de Educação Fundamental. Parâmetros curriculares nacionais: introdução aos parâmetros curriculares nacionais. Brasília, DF: MEC/SEF, 1997. p. 301. Disponível em: http://portal.mec.gov.br/seb/arquivos/pdf/livro01.pdf. Acesso em: 30 maio 2019. 
ISSN 1981-3694

(DOI): $10.5902 / 1981369438872$

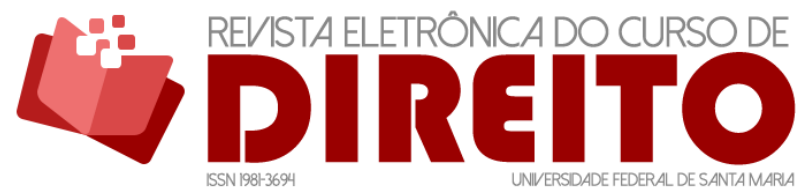

DAS CONSEQUÊNCIAS DA DEMONIZAÇÃO DA PLURALIDADE NAS

ESCOLAS À LUZ DO ESTATUTO DA DIVERSIDADE SEXUAL E DE

GÊNERO

VALERIA SILVA GALDINO CARDIN RAISSA ARANTES TOBBIN

próprio corpo, das normas sociais que ditam o que é feminino e masculino e dos padrões sexuais relacionados ao gênero. Assim, é fundamental que a escola seja um recinto de informação, de transmissão do conhecimento científico e cultural, um ambiente de diálogo e disposto a enfrentar os principais temas que estão em voga na vida social. Como demonstrado pelos principais instrumentos nacionais que regulam a Educação brasileira, não cabe à escola impor à sociedade um modelo de família, de conduta religiosa ou de ideologia política. 0 papel desta é apenas reconhecer, acolher e propor reflexões críticas acerca da pluralidade de concepções e dos diversos modos de vida e de pensamento.

Por outro lado, a escola também não pode ceder às exigências de setores mais conservadores da sociedade e deixar de propor o diálogo quanto ao gênero e à sexualidade, visto que o meio escolar, por vezes, é o único local detentor de capacidade de confronto e de combate a concepções e ideais preconceituosos e discriminatórios. A diversidade sexual e de gênero não é fenômeno controlável por vias segregatórias ou marginalizantes, visto que persiste mesmo diante da falta de proteção jurídica e da omissão estatal, especialmente legislativa. Logo, é realidade que se impõe e que se sobrepõe aos padrões e aos estereótipos sociais que não condizem com o Estado Democrático de Direito ou com a aceitação da diferença. A escola da pós-modernidade é laica e deve ser orientada por ideais inclusivos e nunca por aqueles que privilegiem apenas um viés de discurso, em detrimento de outros menos aceitos pela moral hetero-cis-normativa.

A educação ainda é a melhor forma de rompimento com as desigualdades sociais e econômicas, uma vez que proporciona grandes possibilidades de crescimento e de aprimoramento pessoal do indivíduo. A falta de educação formal é uma das principais causas de exclusão social de pessoas pertencentes à comunidade LBGTQI+, que não encontram na escola um ambiente receptivo; pelo contrário, o encaram como espaço que provoca medo, ansiedade, passível de bullying e de violência. Tal cenário apenas contribui para a dificuldade de inserção desses indivíduos no mercado de trabalho e econômico, e no acesso ao sistema de saúde.

Por óbvio que a escola não detém capacidades messiânicas de sozinha, acabar com o preconceito, mas é plenamente possível que seja um ambiente de aceitação da diversidade, uma vez que, se a escola não for um recinto acolhedor, qual será? Que outro ambiente de tamanha magnitude e extensão proporá, sem pressões políticas e sociais, por intenções legítimas e não meramente comerciais ou midiáticas, ser iniciador de reflexões, estudos e pesquisas acerca desse tema? Logo, diante da já mencionada potencialidade que a escola possui de ser um ambiente minimamente transformador, as controvérsias que envolvem o termo "ideologia de 
ISSN 1981-3694

(DOI): $10.5902 / 1981369438872$

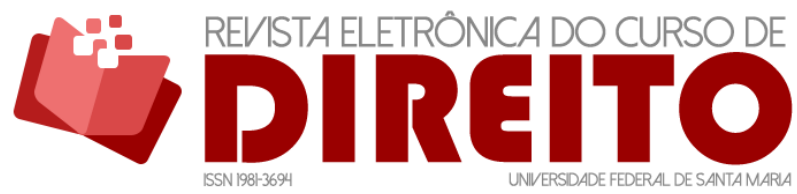

DAS CONSEQUÊNCIAS DA DEMONIZAÇÃO DA PLURALIDADE NAS ESCOLAS À LUZ DO ESTATUTO DA DIVERSIDADE SEXUAL E DE

GÊNERO

VALERIA SILVA GALDINO CARDIN RAISSA ARANTES TOBBIN

gênero" contribuem para a dissimulação de agendas e de interesses contrários à diversidade, à educação e à concretização de uma sociedade mais justa e igualitária. Tal visão não coaduna, pelo contrário, se opõe ao que diz o sistema internacional de proteção dos direitos humanos; os preceitos constantes na Constituição Federal de 1988; os principais documentos oficiais que orientam a Educação brasileira; e os estudos acadêmicos e científicos acerca da importância dos direitos sexuais e reprodutivos para o desenvolvimento da personalidade do indivíduo.

Notadamente, pode ter fundamento no campo da fé, da religião e da concepção individual de cada cidadão, que, inclusive, deve ser tutelada, mas não pode ser vista como política, defesa ou agenda de figuras centrais e representativas, para as quais outorga-se a gestão da coisa pública, de um Estado que se intitula Democrático de Direito e que possui suas relações internacionais orientadas pela defesa dos direitos humanos ou que busca a concretização de uma igualdade material e não meramente formal, que por séculos impediu e respaldou a omissão estatal frente a políticas inclusivas e afirmativas e capazes de melhor combater a violência, a desigualdade e o preconceito, altamente maléficos aos propósitos da humanidade. A educação de gênero é, em última instância, um direito humano, essencial à formação da personalidade do indivíduo; logo, também crucial para uma vida saudável, para a inclusão social, para a capacidade de auto aceitação, de tolerância e de respeito à diferença. Ainda, é garantia crucial para a possibilidade de concretização da felicidade, direito já reconhecido pela doutrina e pela jurisprudência na seara jurídica.

\section{REFERÊNCIAS}

ALVES, José Esutáquio Diniz. “O Choque de Civilizações” versus Progressos Civilizatórios. In: CAETANO, André Junqueira; ALVES, José Eustáquio Diniz; CORRÊA, Sônia (orgs.). Dez anos do CAIRO: tendências da fecundidade e direitos reprodutivos no Brasil. Campinas: ABEP, 2004. p. $19-40$.

BARONE, Isabelle. Quem ensina sexo para a criança é "o papai e a mamãe" e não a escola, como diz Bolsonaro? Gazeta do Povo, 27 abr. 2019. Disponível em:

https: / /www.gazetadopovo.com.br/educacao/quem-ensina-sexo-para-a-crianca-e-o-papai-e-aa-mamae-diz-bolsonaro-o-que-dizem-especialistas/. Acesso em: 20 jun 2019.

BARIFOUSE, Rafael. STF aprova a criminalização da homofobia. BBC News Brasil, São Paulo, 13 jun. 2019. Disponível em: https://www.bbc.com/portuguese/brasil-47206924. Acesso em: 14 jun 2019. 
ISSN 1981-3694

(DOI): $10.5902 / 1981369438872$

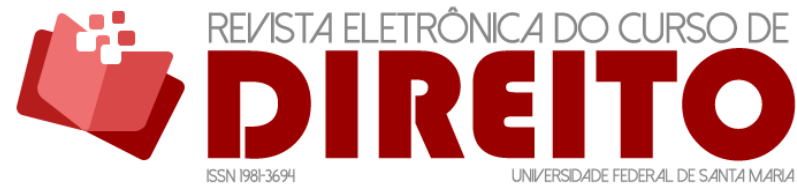

DAS CONSEQUÊNCIAS DA DEMONIZAÇÃO DA PLURALIDADE NAS ESCOLAS À LUZ DO ESTATUTO DA DIVERSIDADE SEXUAL E DE

GÊNERO

VALERIA SILVA GALDINO CARDIN RAISSA ARANTES TOBBIN

BARROSO suspende norma municipal que proibia ensino sobre gênero e sexualidade. Revista Consultor Jurídico, 30 ago. 2018. Disponível em: https://www.conjur.com.br/2018-ago30/barroso-suspende-norma-proibia-ensino-genero-palmas. Acesso em: 28 maio 2019.

BATISTA, Cristiano; COSTA, Fabrício Veiga; FREITAS, Sérgio Henriques Zandona. O equívoco do movimento "escola sem partido" num contexto constitucional de educação democrática, inclusiva e emancipatória. In: COSTA, Fabrício Veiga; MOTTA, Ivan Dias da; FREITAS, Sérgio Henrique Zandona. (orgs.). Proposições crítico-reflexivas sobre o direito à educação na sociedade contemporânea. Coleção Caminhos Metodológicos do Direito. Maringá: IDDM, 2017. p. 198-225.

BRASIL. Instituto Nacional de Estudos e Pesquisas Educacionais Anísio Teixeira. Plano Nacional de Educação PNE 2014-2024: Linha de Base. Brasília, DF: Inep, 2015. Disponível em: http://portal.inep.gov.br/documents/186968/485745/Plano+Nacional+de+Educa\%C3\%A7\%C3\%A3 o+PNE+2014-2024++Linha+de+Base/c2dd0faa-7227-40ee-a520-12c6fc77700f?version=1.1. Acesso em: 28 maio 2019.

BRASIL. Lei $n^{\circ}$ 9.394, de 20 de dezembro de 1996. Estabelece as diretrizes e bases da educação nacional. Brasília, DF: Presidência da República, [2019]. Disponível em: http://www.planalto.gov.br/ccivil_03/leis/19394.htm. Acesso em: 30 maio 2019.

BRASIL. Secretaria de Educação Fundamental. Parâmetros curriculares nacionais: orientação sexual. Brasília, DF: MEC/SEF, 1997. Disponível em:

https: //cptstatic.s3.amazonaws.com/pdf/cpt/pcn/volume-10-6-temas-transversais-orientacaosexual.pdf. Acesso em: 28 maio 2019.

BRASIL. Senado Federal. Projeto de Lei do Senado $n^{\circ}$ 134, de 2018. Institui o Estatuto da Diversidade Sexual e de Gênero. Disponível em:

https://www25.senado.leg.br/web/atividade/materias/-/materia/132701. Acesso em: 20 maio 2019.

BRASIL. Supremo Tribunal Federal. Recurso Extraordinário 898.060. Repercussão Geral 622 Prevalência da paternidade socioafetiva em detrimento da paternidade biológica. Relator: Ministro Luiz Fux. Data de Julgamento: 22 set. 2016. Disponível em:

http: //www.stf.jus.br/portal/jurisprudenciarepercussao/verAndamentoProcesso.asp?incidente= 4803092\&numeroProcesso=898060\&classeProcesso=RE\&numeroTema=622\#. Acesso em: 28 maio 2019.

BRASIL. [Constituição (1988)]. Constituição da República Federativa do Brasil de 1988. Brasília, DF: Presidência da República, [2016]. Disponível em:

http://www.planalto.gov.br/ccivil_03/constituicao/constituicao.htm. Acesso em: 20 maio 2019.

CARDIN, Valéria Silva Galdino; SEGATTO, Antonio Carlos; CAZELATTO, Caio Eduardo Costa. 0 exercício ilegítimo do discurso de ódio homofóbico sob a ótica da sexualidade e da dignidade humana. In: Revista Jurídica - UNICURITIBA, Curitiba, v. 1, n. 46, p. 90-118, 2017. Disponível em: http://revista.unicuritiba.edu.br/index.php/RevJur/article/view/2001. Acesso em: 22 maio 2019.

CARVALHO, Maria Eulina Pessoa de; RABAY, Glória. Usos e incompreensões do conceito de gênero no discurso educacional no Brasil. Revista Estudos Feministas, Florianópolis, v. 23, n. 1, 
ISSN 1981-3694

(DOI): $10.5902 / 1981369438872$

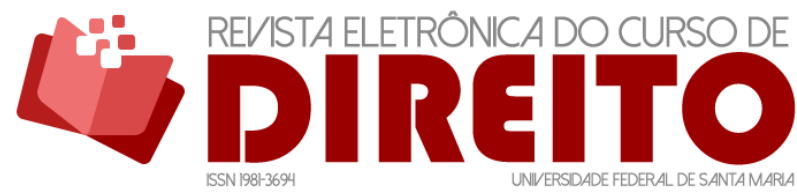

DAS CONSEQUÊNCIAS DA DEMONIZAÇÃO DA PLURALIDADE NAS ESCOLAS À LUZ DO ESTATUTO DA DIVERSIDADE SEXUAL E DE

GÊNERO

VALERIA SILVA GALDINO CARDIN RAISSA ARANTES TOBBIN

p. 119-136, jan./abr. 2015. Disponível em:

https://periodicos.ufsc.br/index.php/ref/article/view/37466/28761. Acesso em: 21 maio 2019.

CAYE, Daniel Paulo; MARQUES, Cláudia Lima. Os Princípios de Yogyakarta e sua interação com o Direito Interno e Políticas Públicas no Brasil. In: SALÃO DE INICIAÇÃO CIENTíFICA PUCRS, 10., 2009. Anais [...]. 2009. p. 2675. Diponível em:

http://www.pucrs.br/edipucrs/XSalaolC/Ciencias_Sociais_Aplicadas/Direito/70358-

DANIEL_PAULO_CAYE.pdf. Acesso em: 3 maio 2020.

CAZELATTO, Caio Eduardo Costa; CARDIN, Valéria Silva Galdino. 0 discurso de ódio e minorias sexuais. Rio de Janeiro: Lumen Juris, 2018.

CERIONI, Clara. Menino veste azul e menina veste rosa, diz Damares em vídeo. Exame, 3 jan. 2019. Disponível em: https: / / exame.abril.com.br/brasil/menino-veste-azul-e-menina-veste-rosa-diz-damares-emvideo/. Acesso em: 20 jun. 2019.

COSTA, Ronaldo Pamplona da. Os onze sexos: as múltiplas faces da sexualidade humana. 4. ed. São Paulo: Kondo Editora, 2005.

DIAS, Maria Berenice. Um estatuto para a diversidade sexual. In: PEREIRA, Rodrigo da Cunha. Família: entre o público e o privado (coord.). Porto Alegre: Magister/IBDFAM, 2012. p. 176-192.

DINIZ, Maria Helena. Curso de Direito Civil brasileiro: Direito de Família. 24. ed. São Paulo: Saraiva, 2009.

FISCHMANN, Roseli. Estado Laico, Educação, Tolerância e Cidadania ou simplesmente não crer. São Paulo: Factash, 2012.

LÔBO, Paulo. Direito de Família e os princípios constitucionais. In: Tratado de Direito das Famílias. 2. ed. Belo Horizonte: IBDFam, 2016. p. 103-131.

LONGARAY, Deise Azevedo; RIBEIRO, Paula Regina Costa. A homossexualidade e a homofobia no espaço escolar: analisando algumas estratégias de controle. In: MAIO, Eliane Rose; CORREA, Crishna Mirella de Andrade. (orgs). Gênero, direito e diversidade sexual: trajetórias escolares. Maringá: Uduem, 2013.

MACHADO, Carla Silva. Gênero, sexualidade e a importância de práticas pedagógicas interculturais. In: Revista Reflexão e Ação, Santa Cruz do Sul, v. 24, n. 1, p. 177-191, jan./abr. 2016. Disponível em: https://online.unisc.br/seer/index.php/reflex/article/view/6992/pdf. Acesso em: 25 maio 2019.

MAIA, Marcos Felipe Gonçalves; ROCHA, Damião. Ideologia de Gênero: tensões e desdobramentos na educação. In: Revista Contemporânea de Educação, v. 12, n. 25, p. 402-419, set./dez. 2017. Disponível em: https://revistas.ufrj.br/index.php/rce/article/view/3690/pdf. Acesso em: 22 maio 2019.

MARCON, Amanda Nogara; PRUDÊNCIO, Luísa Evangelista Vieira; GESSER, Marivete. Políticas públicas relacionadas à diversidade sexual na escola. In: Revista Psicologia Escolar e Educacional, São Paulo, v. 20, n. 2, p. 291-301, maio/ago. 2016. Disponível em: 
ISSN 1981-3694

(DOI): $10.5902 / 1981369438872$

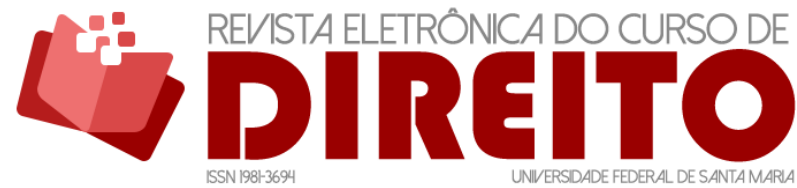

DAS CONSEQUÊNCIAS DA DEMONIZAÇÃO DA PLURALIDADE NAS ESCOLAS À LUZ DO ESTATUTO DA DIVERSIDADE SEXUAL E DE

GÊNERO

VALERIA SILVA GALDINO CARDIN RAISSA ARANTES TOBBIN

http://www.scielo.br/pdf/pee/v20n2/2175-3539-pee-20-02-00291.pdf. Acesso em: 29 maio 2019.

MARIANO, Ricardo; GERARDI, Dirceu André. Eleições presidenciais na América Latina em 2018 e ativismo político. In: Revista USP, n. 120, p. 61-76, jan./mar. 2019. Disponível em:

https://www.revistas.usp.br/revusp/article/view/155531/151189. Acesso em: 20 jun 2019.

MENA, Fernanda. Mais da metade dos LGBT diz ter sofrido violência desde as eleições. Folha de São Paulo, 20 mar. 2019. Disponível em:

https: / / www1.folha.uol.com.br/cotidiano/2019/03/mais-da-metade-dos-lgbt-diz-ter-sofridoviolencia-desde-as-eleicoes.shtml. Acesso em: 16 jun 2019.

MINISTRO suspende lei de Foz do Iguaçu (PR) que proíbe abordagem sobre gênero nas escolas municipais. Notícias STF, 5 jul. 2018. Disponível em:

http://www.stf.jus.br/portal/cms/verNoticiaDetalhe.asp?idConteudo=383353. Acesso em: 28 maio 2019.

MISKLOCI, Richard; CAMPANA, Maximiliano. “Ideologia de gênero": notas para a genealogia de um pânico moral contemporâneo. Revista Sociedade e Estado, v. 32, n. 3, p. 725-747, set./dez. 2017. Disponível em: http://www.scielo.br/pdf/se/v32n3/0102-6992-se-32-03-725.pdf. Acesso em: 21 maio 2019.

ORDEM DOS ADVOGADOS DO BRASIL (OAB). Conselho Federal. Comissão Especial da Diversidade Sexual e de Gênero. Anteprojeto de Lei. Estatuto da Diversidade Sexual e de Gênero. 2017. Disponível em: https: / /legis.senado.leg.br/sdleg-

getter/documento?dm=7302364\&disposition=inline. Acesso em: 20 maio 2019.

PEREIRA, Maycon Samuel Xavier; SANTOS, Marcelo Loeblein dos. Igualdade de gênero nas relações de trabalho: superando os estereótipos entre homem e mulher. In: Revista Eletrônica do Curso de Direito da UFMS, Santa Maria, v. 5, n. 2, 2010. Disponível em:

https://periodicos.ufsm.br/revistadireito/article/view/7051/4264. Acesso em: 20 maio 2019.

PIOVESAN, Flávia; SILVA, Roberto B. Dias da. Igualdade e diferença: o direito à livre orientação sexual na Corte Europeia de Direito Humanos e no Judiciário brasileiro. In: BUGLIONE, Samantha; VENTURA, Miriam. (orgs.). Direito à reprodução e à sexualidade: uma questão de ética e justiça. Rio de Janeiro: Lumen Juris, 2010. p. 65-105.

PRINCÍPIOS DE YOGYAKARTA. Princípios sobre a aplicação da legislação internacional de direitos humanos em relação à orientação sexual e identidade de gênero. 2006. Disponível em: www.clam.org.br/uploads/conteudo/principios_de_yogyakarta.pdf. Acesso em: 30 maio 2019.

QUEIROGA, Louise. Brasil segue no primeiro lugar do ranking de assassinatos de transexuais. 0 Globo, 14 nov. 2018. Disponível em: https://oglobo.globo.com/sociedade/brasil-segue-noprimeiro-lugar-do-ranking-de-assassinatos-de-transexuais-23234780. Acesso em: 29 maio 2019.

REIS, Toni; EGGERT, Edla. Ideologia de Gênero: uma falácia construída sobre os planos de educação brasileiros. In: Educação e Sociedade, Campinas, v. 38, n. 138, p. 9-26, jan./mar. 2017. Disponível em: http://www.scielo.br/pdf/es/v38n138/1678-4626-es-38-138-00009.pdf. Acesso em: 21 maio 2019. 
ISSN 1981-3694

(DOI): $10.5902 / 1981369438872$

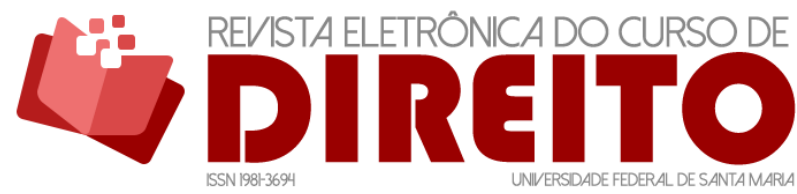

DAS CONSEQUÊNCIAS DA DEMONIZAÇÃO DA PLURALIDADE NAS ESCOLAS À LUZ DO ESTATUTO DA DIVERSIDADE SEXUAL E DE

GÊNERO

RIBEIRO, Cláudia Maria. Gênero e sexualidade no cotidiano de processos educativos: "apesar de tanta sombra, apesar de tanto medo". In: MAIO, Eliane Rose; CORREA, Crishna Mirella de Andrade (orgs.). Gênero, direitos e diversidade sexual: trajetórias escolares. Maringá: UEM, 2013.

RODRIGUES, Edwirges Elaine; ALVARENGA, Maria Amália de Figueiredo Pereira. Transexualidade e dignidade da pessoa humana. In: Revista Eletrônica do Curso de Direito da UFMS, Santa Maria, v. 10, n. 1, p. 72-93, 2015. Disponível em:

https://periodicos.ufsm.br/revistadireito/article/view/18583. Acesso em: 13 maio 2019.

ROSISTOLATO, Rodrigo Pereira da Rocha. Gênero e cotidiano escolar: Gênero e cotidiano escolar: dilemas e perspectivas da dilemas e perspectivas da intervenção escolar na socialização afetivo socialização afetivo-sexual dos -sexual dos adolescentes. In: Revista Estudos Feministas, Florianópolis, v. 17, n. 1, p. 11-30, jan./abr. 2009. Disponível em:

http://www.scielo.br/pdf/ref/v17n1/a02v17n1.pdf. Acesso em: 29 maio 2019.

SANTANA, Cassia. TJ libera debate sobre ideologia de gênero nas escolas de Itaporanga. InfoNet, 19 jun. 2019. Disponível em: https://infonet.com.br/noticias/educacao/tj-libera-debate-sobreideologia-de-genero-nas-escolas-de-itaporanga/. Acesso em: 20 jun 2019.

SILVA, Ana Maria Zanoni. Por uma educação dialógica. In: FINOTTI, Laura Fontes Tomaz; TOMAZ, Loyana Chirstian de Lima; TOMAZ, Rozaine Aparecida Fontes. (orgs.). Educação e

interdisciplinaridade: diálogos com a psicologia, a filosofia e o direito. Uberlândia: Composer, 2015. p. 241-256.

SEFFNER, Fernando; PICHETTI, Yara de Paula. A quem tudo quer saber, nada se the diz: uma educação sem gênero e sem sexualidade é desejável? In: Revista Reflexão e Ação, Santa Cruz do Sul, v. 24, n. 1, p. 61/81, jan./abr. 2016. Disponível em:

https://online.unisc.br/seer/index.php/reflex/article/view/6986/pdf. Acesso em: 20 maio 2019.

STF reconhece a transgêneros possibilidade de alteração de registro civil sem mudança de sexo. Notícias STF, 1 mar. 2018. Disponível em:

http://www.stf.jus.br/portal/cms/verNoticiaDetalhe.asp?idConteudo=371085. Acesso em: 28 maio 2019.

SUPREMO reconhece união homoafetiva. NOTÍCIAS STF, 5 maio 2011. Disponível em: http://www.stf.jus.br/portal/cms/verNoticiaDetalhe.asp?idConteudo=178931. Acesso em: 28 maio 2019.

SUSPENSA norma que proibia abordagem de questões de gênero nas escolas de Palmas (TO). Notícias STF, 27 ago. 2018. Disponível em:

http://stf.jus.br/portal/cms/verNoticiaDetalhe.asp?idConteudo=388055. Acesso em: 22 maio 2019.

UNITED NATIONS (ONU). Universal Declaration of Human Rights. 1948. Disponível em: https://www.ohchr.org/EN/UDHR/Pages/Language.aspx?LangID=por. Acesso em: 30 maio 2019. 
ISSN 1981-3694

(DOI): $10.5902 / 1981369438872$

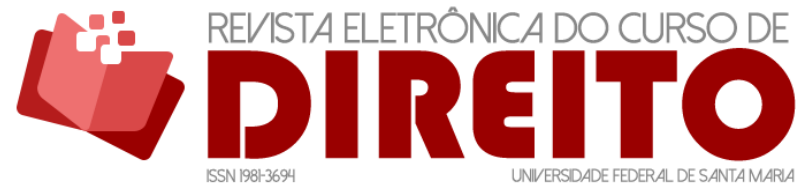

DAS CONSEQUÊNCIAS DA DEMONIZAÇÃO DA PLURALIDADE NAS

VIEIRA, Tereza Rodrigues. Direito à diversidade de gênero, redesignações identitárias e o Estatuto da Diversidade Sexual. In: PEREIRA, Rodrigo da Cunha. Família: entre o público e o privado (coord.). Porto Alegre: Magister/IBDFAM, 2012. p. 359-369.

VIEIRA, Tereza Rodrigues; SAMPAIO, Liliana Lopes Pedral. Personalidade, identidade civil e autorreconhecimento: consequências psicológicas causadas por um prenome indesejado. In: MIRANDA, José Eduardo; CARDIN, Valéria Silva Galdino. (orgs.). Direitos da personalidade: reconhecimento, garantias e perspectivas. Curitiba: Juruá, 2018. p. 105-120.

XAVIER, Gláucia do Carmo. Transexualidade no Ensino Médio: desafios e possibilidades. In: Cadernos de Gênero e Diversidade, Salvador, v. 5, n. 1, p. 79-95, jan./mar. 2019. Disponível em: https://portalseer.ufba.br/index.php/cadgendiv/article/view/31931/18993. Acesso em: 22 maio 2019.

\section{COMO FAZER REFERÊNCIA AO ARTIGO (ABNT):}

CARDIN, Valeria Silva Galdino; TOBBIN, Raissa Arantes. Discurso de ódio político: as consequências da demonização da pluralidade nas escolas à luz do Estatuto da Diversidade Sexual e de Gênero. Revista Eletrônica do Curso de Direito da UFSM, Santa Maria, RS, v. 15, n. 1, e38872, jan./abr. 2020. ISSN 19813694. DOI: http://dx.doi.org/10.5902/1981369438872. Disponível em: https://periodicos.ufsm.br/revistadireito/article/view/38872. Acesso em: dia mês. ano.

Direitos autorais 2020 Revista Eletrônica do Curso de Direito da UFSM Editores responsáveis: Rafael Santos de Oliveira e Angela Araujo da Silveira Espindola

Esta obra está licenciada com uma Licença Creative Commons Atribuição-NãoComercial-SemDerivações 4.0 Internacional.

\section{SOBRE AS AUTORAS}

\section{VALERIA SILVA GALDINO CARDIN}

Pós-Doutora em Direito pela Universidade de Lisboa; Doutora e Mestre em Direito das Relações Sociais pela Pontifícia Universidade Católica de São Paulo (PUCSP); Docente da Universidade Estadual de Maringá (UEM) e no Doutorado e Mestrado do Programa de Pós-Graduação em Ciências Jurídicas pelo Centro Universitário de Maringá (UNICESUMAR); Pesquisadora e Bolsista Produtividade em Pesquisa do Instituto Cesumar de Ciência, Tecnologia e Inovação (ICETI); Coordenadora do Grupo de Pesquisa Reconhecimento e Garantia dos Direitos da Personalidade (CNPq); Advogada no Paraná.

\section{RAISSA ARANTES TOBBIN}

Mestranda em Ciências Jurídicas pelo Centro Universitário de Maringá (UNICESUMAR); Graduada em Direito pela Universidade Paranaense (UNIPAR); Graduada em Letras - Português/Espanhol; Membra do Grupo de Pesquisa Reconhecimento e Garantia dos Direitos da Personalidade (CNPq; Advogada no Paraná. 